\title{
Role of Extracellular Vesicles in Cell Death and Inflammation
}

\author{
Rahul Sanwlani ${ }^{1}$ and Lahiru Gangoda ${ }^{1,2,3, *}$ \\ 1 Department of Biochemistry and Genetics, La Trobe Institute for Molecular Science, La Trobe University, \\ Melbourne, VIC 3083, Australia; 19168073@students.latrobe.edu.au \\ 2 The Walter and Eliza Hall Institute of Medical Research (WEHI), 1G Royal Parade, Parkville, \\ Melbourne, VIC 3052, Australia \\ 3 Department of Medical Biology, University of Melbourne, Parkville, Melbourne, VIC 3010, Australia \\ * Correspondence: Gangoda.L@wehi.edu.au
}

check for updates

Citation: Sanwlani, R.; Gangoda, L. Role of Extracellular Vesicles in Cell Death and Inflammation. Cells 2021, 10, 2663. https://doi.org/10.3390/ cells10102663

Academic Editor: Francesc E. Borràs

Received: 9 September 2021

Accepted: 4 October 2021

Published: 5 October 2021

Publisher's Note: MDPI stays neutral with regard to jurisdictional claims in published maps and institutional affiliations.

Copyright: (c) 2021 by the authors. Licensee MDPI, Basel, Switzerland. This article is an open access article distributed under the terms and conditions of the Creative Commons Attribution (CC BY) license (https:// creativecommons.org/licenses/by/ $4.0 /)$.

\begin{abstract}
Extracellular vesicles (EVs) have been identified as novel mediators of intercellular communication. They work via delivering the sequestered cargo to cells in the close vicinity, as well as distant sites in the body, regulating pathophysiological processes. Cell death and inflammation are biologically crucial processes in both normal physiology and pathology. These processes are indistinguishably linked with their effectors modulating the other process. For instance, during an unresolvable infection, the upregulation of specific immune mediators leads to inflammation causing cell death and tissue damage. EVs have gained considerable interest as mediators of both cell death and inflammation during conditions, such as sepsis. This review summarizes the types of extracellular vesicles known to date and their roles in mediating immune responses leading to cell death and inflammation with specific focus on sepsis and lung inflammation.
\end{abstract}

Keywords: extracellular vesicles; exosomes; microvesicles; apoptotic bodies; apoptotic extracellular vesicles; cell death; inflammation; sepsis; lung inflammatory disorders; SARS-CoV-2

\section{Extracellular Vesicles: Introduction, Subtypes, and Cargo}

Extracellular vesicles (EVs) have been defined as nanosized vesicles that are shed into extracellular space [1]. First identified in differentiating reticulocytes three decades ago, EVs were thought to be the waste disposal system of cells which aided in the elimination of cellular waste [2,3]. However, extensive studies over the past two decades have been crucial for introducing a paradigm shift by ascertaining a more sophisticated role for EVs [4]. Intercellular communication is no more thought to be a consequence of only direct cell-cell contact or secreted factors such as hormone signaling. EVs are now known to mediate multiple pathophysiological processes by facilitating intercellular communication [5]. Their expansive role in health and disease has been investigated in multiple models [6,7]. As more studies continue to shed light on the diverse role played by EVs, their role is now becoming apparent to be crucial in not just mediating communication between distant cells in an individual but also in facilitating the transfer of bioactive compounds inter-individual, cross-species and even inter-kingdom [8-10].

Multiple subtypes of eukaryotic EVs exist and they are primarily categorized based on their biogenesis, subcellular origin, and size (Figure 1) [1,11]. Exosomes are vesicles that are endocytic in origin and shed as a consequence of multivesicular bodies (MVB) or late endosomes fusing with the plasma membrane [12]. They range in size from 30 to $150 \mathrm{~nm}$ and were believed to be the smallest EV subtype until the recently [1,13]. Exomeres have been identified as secretory nanoparticles that are less than $50 \mathrm{~nm}$ in size with their mode of biogenesis currently unknown $[14,15]$, whereas shedding microvesicles (MVs) are larger in size and may range from 100 to $1000 \mathrm{~nm}$. They originate due to budding or outward vesiculation of plasma membrane, thus also referred to as ectosomes [1,16]. Furthermore, there are new classes of EVs defined, such as migrasomes and large oncosomes [17-19]. Up until now, apoptotic cells were thought to only shed apoptotic bodies (ApoBDs) which 
are similar to microvesicles in origin as they emerge due to budding of plasma membrane. However, ApoBDs are larger in size and may range from 50 to $5000 \mathrm{~nm}[20,21]$. More recently, apoptotic cells were found to partake in secretion of other EV subtypes and apoptotic cell-derived EVs (ApoEVs) now include apoptotic microvesicles (ApoMVs) and apoptotic exosomes (ApoExos) which are physiologically distinct from ApoBDs [22]. Similar to MVs, ApoMVs range in size from 200 to $1000 \mathrm{~nm}$ and also called apoptotic microparticles. They have a higher membrane integrity than ApoBDs, promoting better molecular exchange [22-24], whereas ApoExos are the most recent addition to ApoEVs and were initially reported to be released by endothelial cells following caspase 3-dependent MVB formation $[25,26]$. Though there is limited knowledge regarding their origin and function, they continue to be explored in-depth as final messengers of apoptotic cells [22].

A

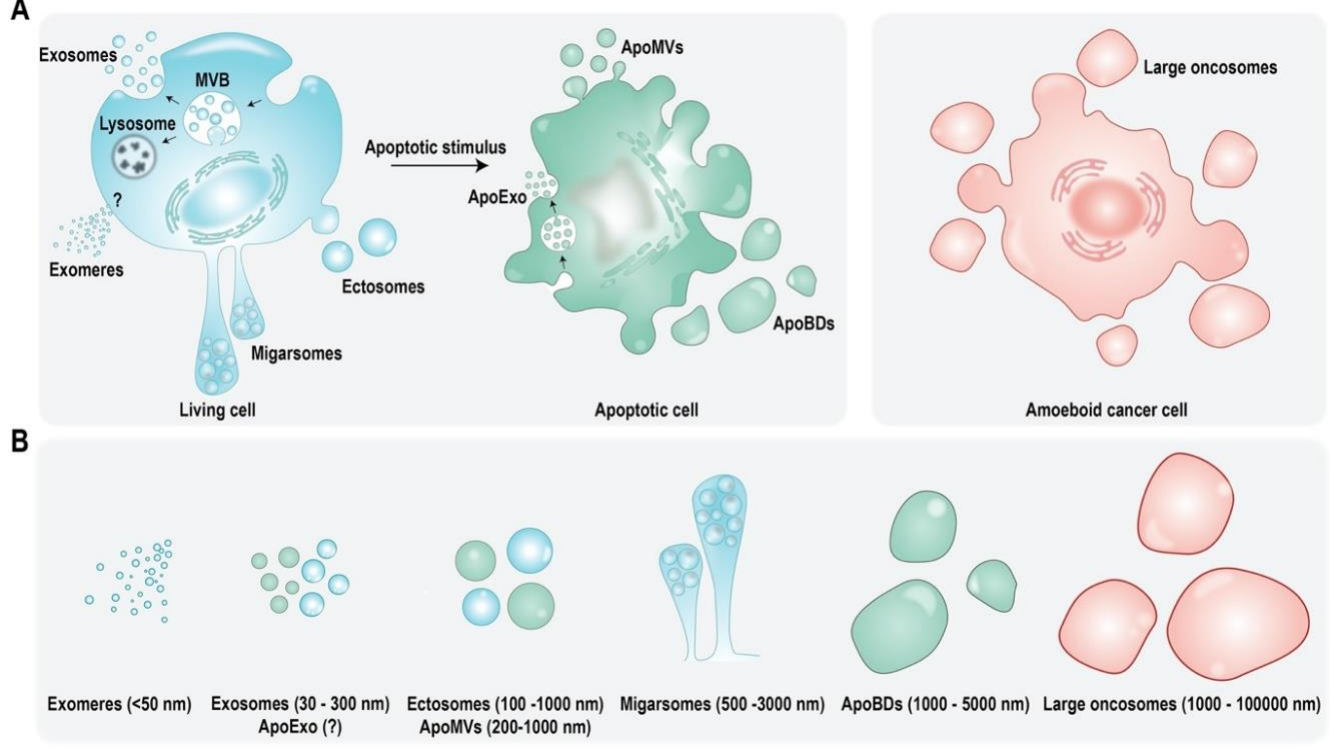

Figure 1. Schematic representation of EV subtypes identified in eukaryotic cells. (A) Although live cells were initially thought to shed exosomes and microvesicles, recent developments have identified novel EV subtypes including exomeres and migrasomes, whereas cancer cells also partake in secretion of large oncosomes. On the contrary, apoptotic cells which were long though to shed only ApoBDs are now known to secrete other EV subtypes including ApoMVs and ApoExos. (B) Various EV subtypes shed by live or apoptotic cells are distinct in their biogenesis, cargo, origin, and size.

EVs contain a diverse cargo comprising of a plethora of proteins, nucleic acids and lipids [27]. EV cargo is capable of mediating a variety of responses in the recipient cell including infections [28], signal transduction [29] and immune regulation [30]. EV cargo is not only different for various subtypes of EVs but also varies between same EV subtype derived from two different cell types [31,32]. EV proteome is its most well studied cargo so far [27]. Exosomes have been particularly found to be enriched with endosome associated proteins with documented roles in vesicle trafficking, such as Rabs, Annexins, and Flotillins. Furthermore, Alix and TSG101 have been previously claimed as molecular markers of exosomes [5,12]. However, even though these proteins with a role in MVB biogenesis are enriched in exosomes, they are not markers as previously claimed [1]. Exosomes have also been found to be enriched with heat shock proteins (HSPs), and membrane proteins, such as integrins, major histocompatibility complex (MHC) class I and II and tetraspanins CD63, CD9, and CD81 [12,32,33]. MVs on the other hand, having reported roles in metastases, invasion, and inflammation, are enriched with proteins, such as Annexins, selectins, CD40, and metalloproteinases [34,35]. Interestingly, even though ApoEVs have been suggested to have characteristics similar to EVs released by healthy cells, their cargo may enable more distinctive roles. With their unique cargo, ApoEVs may influence processes such as inflammation and autoimmunity in addition to aiding in clearance of apoptotic by-products and remnants. Furthermore, ApoBDs not only contain biomolecule cargo from the originating cell but can also contain nuclear fragments and cellular 
organelles, such as mitochondria and endoplasmic reticulum [20,22,36,37]. Identification of nucleic acids including mRNA, miRNA (miR), and DNA in EVs has generated significant interest $[38,39]$. Functional transfer of nucleic acids via EVs is known to regulate recipient cells and control signaling pathways [40]. Lastly, EVs are abundant in lipids and lipid-related enzymes including but not limited to sphingomyelin, ganglioside, ceramide, cholesterol, and prostaglandins. In fact, EV lipid composition has been observed to be different than that of the cell type of origin [41-43]. Similar to proteins and nucleic acids, lipids in EVs also have functional role in controlling signaling pathways in recipient cells and thus contribute in more ways than only providing structural integrity to these vesicles [44].

\section{EVs as Regulators of Cell Death}

Cell death is an important process that involves the removal of cells during certain developmental stages or those that are compromised due to exposure to toxins. Cell death can also occur as a result of natural processes, where old cells die and are replaced by new ones to maintain homeostasis in an individual. On the contrary, it could also be a result of unnatural factors, such as pathological conditions or local injuries [45]. As established above, cells undergoing apoptosis can shed multiple EV subtypes aiding in not only getting rid of apoptotic debris but also facilitating communication with other cell types. However, the role of EVs in cell death is not only limited to the functions of EVs shed by apoptotic cells. As more studies continue to understand the regulatory potential of EVs, it is becoming increasingly evident that EVs from living cells are also capable of moderating cell death responses in recipient cells (Figure 2). The cargo embodied in EVs is not just dependent on the EV subtype but also the cell type of origin, such as diseased versus healthy cells $[13,46]$. Thus, in a context dependent manner, these signaling moieties may be capable of promoting or attenuating cell death in a particular recipient cell type. The subsequent sections are aimed at elaborating the role of EVs in cell death in various pathophysiological conditions (Tables 1 and 2). As this review specifically addresses the role of EVs in inflammatory disorders, this section would emphasize the role of EVs in mediating immune and inflammatory cell death.

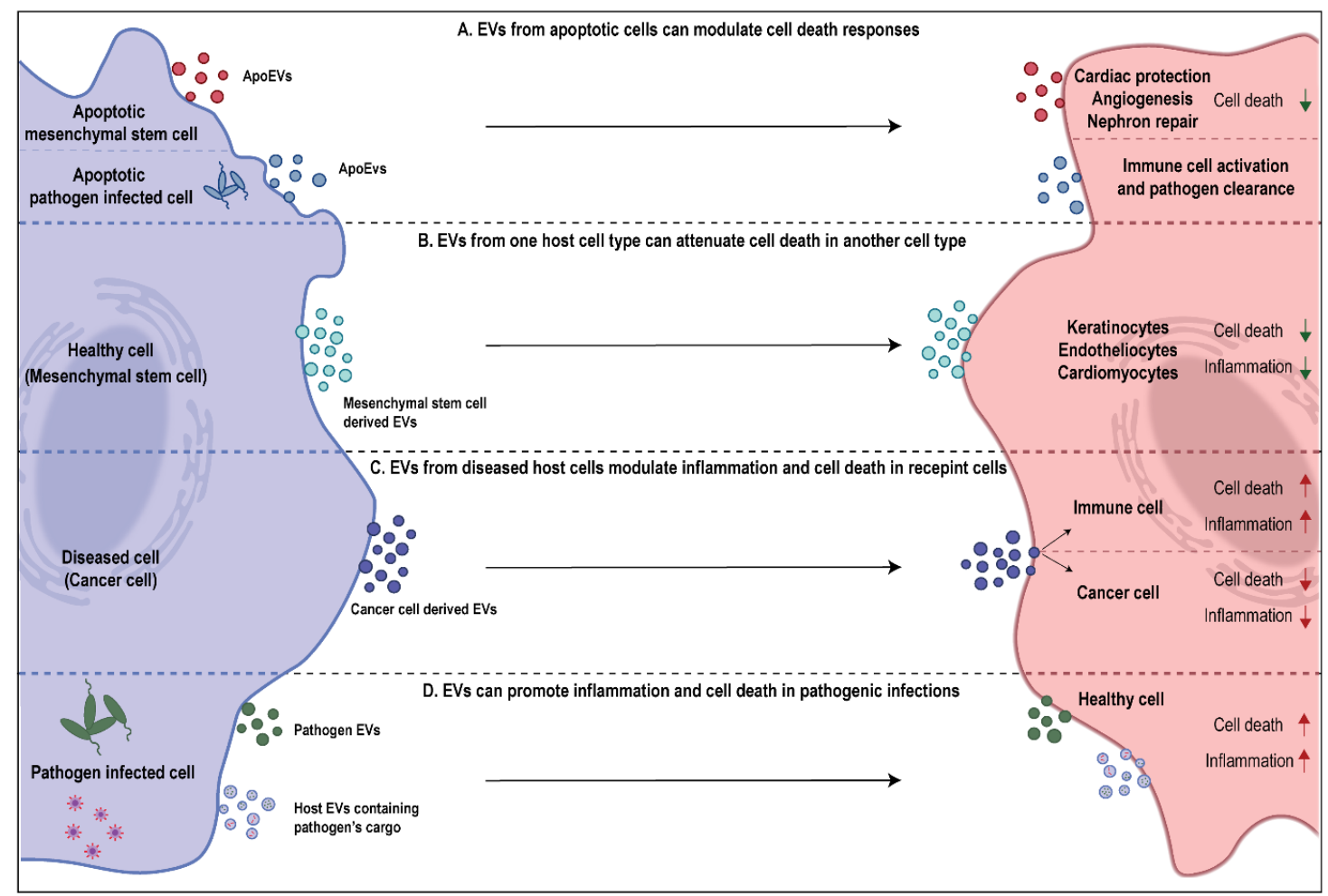

Figure 2. Context dependent roles of EVs in mediating cell death and inflammation. (A) ApoEVs have the ability to 
either attenuate or promote cell death. MSC derived ApoEVs have regenerative function whereas ApoEVs from pathogen infected cells induce activation of immune cells, leading to enhanced targeting and clearance of pathogen cells. (B) Similarly, EVs from healthy MSCs have regenerative function in preventing cell death and inflammation in various cell types. (C) Contrastingly, EVs from diseased host cells may function in different ways depending on the recipient cell. For instance, cancer cell derived EVs promote cell death and inflammation in immune cells but prevent cell death and inflammation in other cancer cells. (D) Infected cells can shed pathogen derived EVs or host EVs loaded with pathogen's cargo. These EVs can promote cell death and inflammation in recipient host cells.

\section{Role of EVs in Attenuating Cell Death}

Attenuation of cell death via extracellular vesicles has been studied in multiple models (Table 1). It has recently been discovered that milk-derived EVs (MEVs) have a role in promoting gut health and development upon uptake by intestinal epithelial cells (IECs) [9] MEVs from multiple sources, such as porcine, bovine and humans have been demonstrated to prevent cell death in IECs during oxidative stress and hypoxia and promote their survival and proliferation [47-49]. This ability of MEVs has been attributed to its cargo inhibiting p53 expression in IECs [50]. However, the role of MEVs in attenuation of cell death may not always be beneficial for the consumer. miR-148a and miR-21 which are a part of MEV cargo have been designated as oncomiRs due to their role in promoting vital cellular processes, such as proliferation and survival by inhibition of tumor suppressor genes [51-53]. Thus, the ability of MEVs to attenuate cell death could be detrimental too. Multiple studies have now demonstrated the ability of tumor cell-derived EVs in promoting survival and preventing cell death in recipient tumor cells (Figure 2). For instance, exosomes from N-myc amplified neuroblastoma cells were found to enhance survival by inducing chemoresistance in non-Nmyc amplified cells, preventing doxorubicin induced apoptosis [54]. Furthermore, in other studies using glioblastoma models, it has been shown that exosomes shed by apoptotic tumor cells were able to confer survival advantage to the surviving glioblastoma cells by transferring spliceosome components [55]. Another model where EVs attenuated cell death, that continues to be increasingly defined with studies, is that of stem cells. The therapeutic nature of mesenchymal stem cells (MSCs) due to paracrine signaling is well established [56]. Recently, it was observed that the MSC derived therapeutic benefits were mediated largely due to EVs. MSC-derived EVs were reported to enhance proliferation and migration of keratinocytes and suppress apoptosis, thus promoting enhanced healing at wound sites [57]. Similarly, MSC-derived EVs are now well known for their cardioprotective function. They have been found to inhibit apoptosis, autophagy and fibrosis by modulating cardiomyocytes and endotheliocytes. Further, MSCs were also found to stimulate cell proliferation and angiogenesis, thus leading to enhanced cardiac survival (Figure 2) [58-60].

Table 1. Table summarizing the studies which elucidate the role of EVs in attenuation of cell death. NS-not specified in the original article.

\begin{tabular}{|c|c|c|c|}
\hline Cargo & EV Source & Function & Reference \\
\hline NS & $\begin{array}{l}\text { Milk (bovine, } \\
\text { porcine, human) }\end{array}$ & Attenuate cell death in IECs & {$[47-50]$} \\
\hline miR-148a, miR-21 & Milk (bovine) & OncomiRs, inhibition of tumor suppressor genes & {$[51-53]$} \\
\hline NS & $\begin{array}{l}\mathrm{N} \text {-myc amplified } \\
\text { neuroblastoma cells }\end{array}$ & $\begin{array}{l}\text { Chemoresistance and enhanced survival in non } \\
\text { N-myc amplified tumor cells }\end{array}$ & [54] \\
\hline $\begin{array}{l}\text { Spliceosome } \\
\text { components }\end{array}$ & $\begin{array}{l}\text { Apoptotic } \\
\text { glioblastoma cells }\end{array}$ & Enhanced survival in recipient tumor cells & [55] \\
\hline NS & MSCs (exosomes) & $\begin{array}{l}\text { Enhance proliferation and survival of keratinocytes, } \\
\text { cardiomyocytes and endotheliocytes }\end{array}$ & {$[57-60]$} \\
\hline NS & MSCs (ApoEVs) & $\begin{array}{l}\text { Regulation of cardiac function and autophagy, } \\
\text { promote nephron repair }\end{array}$ & {$[61,62]$} \\
\hline NS & $\begin{array}{l}\text { Pathogen infected } \\
\text { host cells }\end{array}$ & $\begin{array}{l}\text { Immune regulation and enhanced pathogen } \\
\text { clearance to prevent spread of infection }\end{array}$ & {$[63,64]$} \\
\hline
\end{tabular}


Attenuation of cell death is not necessarily a feature of EVs shed by live cells. ApoEVs which serve as the last messages from dying cells have been thoroughly characterized for the complex role they play in tissue development, regeneration and apoptosis (Figure 2) [65]. Similar to MSC-derived exosomes, MSC-derived ApoEVs have been shown to promote angiogenesis and the recovery of cardiac function via the regulation of autophagy [61]. Further, apoptotic MSC-derived EVs have also been found to have a role in nephron repair following injury. These MSC-derived ApoEV associated benefits could be attributed to compensatory proliferation signaling which has been implied to be consequence of apoptosis [62]. Lastly, ApoEVs released by host cells have been found to indirectly attenuate cell death in surrounding cells by aiding in the regulation of immune system and preventing the spread of pathogen in diseases settings. For instance, ApoMVs shed by macrophages infected with Mycobacterium tuberculosis upon being engulfed by dendritic cells induced antimicrobial immunity. As a consequence, it led to enhanced clearance of the pathogen and prevented further infection of macrophages [63]. A similar phenomenon has also been discovered in the clearance of prion infection by microglia cells upon engulfment of ApoBDs from prion infected neurons [64]. Overall, the ability to EVs to prevent cell death directly or indirectly due to its signaling cargo is evident. These findings highlight the broad untapped therapeutic potential of EVs in controlling diseases and in treating pathological conditions that have so far been extremely challenging to tackle.

\section{Role of EVs in Promoting Cell Death}

The role of EVs in pathological diseases has been extensively studied in host-pathogen interaction model. EVs have evolved as means of communication between host and pathogen by mediating inter-kingdom transfer of cargo. An increasing number of studies over the last decade have highlighted the ability of EVs in facilitating the establishment and accelerated spread of infections in the host. The pathogens have been found to either work by hijacking and exploiting host's machinery or even deploying their own EVs to suppress the host's immune system (Figure 2) [66-69]. For instance, astrocytes infected with Human immunodeficiency virus (HIV) have been shown to shed EVs with the viral Tat protein, leading to neuronal cell death [70]. Similarly, Epstein-Barr virus has been shown to deploy viral components, such as latent membrane protein-1 in EVs shed by infected carcinoma cells, ultimately leading to the alteration of signaling pathways and cell death in T-lymphocytes [71]. Bacterial pathogen Mycobacterium tuberculosis too has been shown to hijack host cell's EV machinery and load virulent cargo in EVs shed by infected macrophages. These EVs were capable of inducing apoptosis in Jurkat T cells [72]. Macrophages infected with bacterial pathogens including Mycobacterium tuberculosis, Salmonella typhimurium, and Toxoplasma gondii have been shown to shed small EVs which contain pathogen associated molecular patters (PAMPs). Upon uptake by uninfected macrophages, these EVs were responsible for elevated cytokine release and resulting pro-inflammatory response [66]. Additionally, it has been shown that EVs shed by a variety of bacterial pathogens themselves harbor virulent cytotoxic cargo which enables them to establish infection in healthy cells and suppress host's defenses [67]. For instance, Gram negative bacterial EVs have been shown to aid in the delivery of lipopolysaccharide (LPS) to the recipient cell's cytosol. This event induces an inflammatory form of cell death, known as pyroptosis, by triggering casapase-11 dependent effector responses [73]. Furthermore, Neisseria gonorrhoeae derived EVs have been shown to contain the Porin protein PorB, which induces apoptosis in host macrophages [74]. Similarly, the presence of Shiga toxin 2a has been observed in pathogen derived EVs and found to have cytotoxic implications via caspase-9 and caspase- 3 activation in human IECs [75].

The role of EVs as promoters of cell death has been elucidated in other pathological conditions too, such as cancer, autoimmunity, and pulmonary disorders (Figure 2). For instance, in a recent study, the role of T-lymphocyte derived exosomes in Type-1 diabetes was explored. Specific miR (miR-142-3p, miR-142-5p, and miR-155) have been found to be enriched in T-lymphocyte derived EVs which led to the elevated incidence of Type-1 
diabetes as they selectively targeted and induced apoptosis in pancreatic $\beta$ cells along with chemokine signaling including $\mathrm{Ccl} 2, \mathrm{Ccl7}$, and $\mathrm{Cxcl10}$ [76]. Tumor cell derived EVs have also been found to use this mechanism to suppress immune response. A recent study showed that exosomal PD-L1 was upregulated and carried in EVs released by metastatic melanomas. These EVs were found to have role in exhaustion of $\mathrm{CD} 8^{+} \mathrm{T}$ cells which aided the tumor cells in evading immune response [30]. Similarly, sera EVs derived from individuals with oral squamous cell carcinoma had elevated expression of Fas ligand which led to T cell apoptosis [77]. In context of lung disorders, such as asthma, airway inflammatory potential of eosinophil derived EVs due to pro-inflammatory cargo has been observed [78]. Further, these EVs were demonstrated to lead to apoptosis in primary alveolar epithelial cells by interfering with JAK/STAT signaling [79]. Similarly, monocyte derived EVs encapsulated caspase- 1 and their ability to induce apoptosis of pulmonary microvascular endothelial cells was observed in acute lung injury (ALI) and acute respiratory distress syndrome (ARDS) $[80,81]$. Another intriguing observation of EV mediated lung pathology and cell death was made in chronic obstructive pulmonary disease (COPD). The apoptotic endothelial cells during COPD shed EVs loaded with inflammatory cargo that promote progression of the disease by inducing apoptosis in otherwise healthy endothelial cells [82]. The subsequent sections further discuss the role of EVs in promoting lung inflammatory disorders in more detail.

The immense potential of EVs as mediators that promote cell death in various pathological conditions has been concretely established (Table 2) and continues to be explored in depth. Collectively, these studies present opportunities to exploit EVs at a therapeutic front for multiple purposes. These findings are key in devising novel therapeutic paradigms and alternatives in treating and preventing the spread of infections, as well as diseases, such as cancer, by targeting EV mediated signaling. Although promising, these studies need further validation with better in vivo models and improved understanding of the molecular mechanisms and cargo components of interest before extrapolating the use of EVs to clinical setups.

Table 2. Table summarizing the studies which elucidate the role of EVs in promoting cell death. NS-not specified in the original article.

\begin{tabular}{|c|c|c|c|}
\hline Cargo & EV Source & Function & Reference \\
\hline HIV Tat protein & HIV infected astrocytes & Neuronal cell death & {$[70]$} \\
\hline $\begin{array}{l}\text { Latent membrane } \\
\text { protein-1, galectin- } 9\end{array}$ & $\begin{array}{c}\text { Epsetien-Barr virus infected } \\
\text { nasopharyngeal } \\
\text { carcinoma cells }\end{array}$ & T lymphocyte cell death & {$[71]$} \\
\hline NS & $\begin{array}{l}\text { Mycobacterium tuberculosis } \\
\text { infected T-lymphocytes }\end{array}$ & Apoptosis in Jurkat T cells & [72] \\
\hline PAMPs & $\begin{array}{l}\text { Pathogen infected } \\
\text { macrophages }\end{array}$ & $\begin{array}{l}\text { Pro-inflammatory cytokine } \\
\text { release in uninfected } \\
\text { macrophages }\end{array}$ & {$[66]$} \\
\hline LPS & Gram negative bacteria & $\begin{array}{l}\text { Caspase-11 mediated } \\
\text { pyroptosis in }\end{array}$ & [73] \\
\hline PorB & Neisseria gonorrhoeae & Apoptosis in macrophages & {$[74]$} \\
\hline Shiga toxin $2 \mathrm{a}$ & Escherichia coli O104:H4 & Cell death in IECs & [75] \\
\hline $\begin{array}{l}\text { miR-142-3p, } \\
\text { miR-142-5p } \\
\text { and miR-155 }\end{array}$ & T-lymphocytes & $\begin{array}{l}\text { Selective targeting and apoptosis } \\
\text { of pancreatic } \beta \text { cells leading to } \\
\text { type- } 1 \text { diabetes }\end{array}$ & {$[76]$} \\
\hline PD-L1 & Metastatic melanomas & $\begin{array}{l}\text { Exhaustion of } \mathrm{CD}^{+} \mathrm{T} \text { cells } \\
\text { leading to immune } \\
\text { response evasion }\end{array}$ & {$[30]$} \\
\hline Fas ligand & $\begin{array}{l}\text { Serum from patients with oral } \\
\text { squamous cell carcinoma }\end{array}$ & $\mathrm{CD}^{+} \mathrm{T}$ cell apoptosis & {$[77]$} \\
\hline
\end{tabular}


Table 2. Cont.

\begin{tabular}{cccc}
\hline Cargo & EV Source & Function & Reference \\
\hline NS & Eosinophils & $\begin{array}{c}\text { Airway inflammation and } \\
\text { apoptosis in primary alveolar } \\
\text { epithelial cells }\end{array}$ & $\begin{array}{c}{[78]} \\
\text { Caspase-1 }\end{array}$ \\
\hline NS & Monocytes & $\begin{array}{c}\text { Apoptosis of pulmonary } \\
\text { microvascular endothelial cells } \\
\text { in ALI and ARDS }\end{array}$ & {$[80,81]$} \\
\hline Apoptotic endothelial cells & $\begin{array}{c}\text { Apoptosis in healthy endothelial } \\
\text { cells in COPD }\end{array}$ & {$[82]$} \\
\hline
\end{tabular}

\section{EVs in Inflammation}

Inflammation is the immune system's response to harmful stimuli, such as pathogens, damaged cells, toxic compounds, or irradiation [83]. Some forms of cell death can provoke inflammatory responses. Although apoptosis is a immunologically silent process and generally does not trigger inflammation, other forms of lytic cell death, such as necrosis and pyroptosis, are pro-inflammatory [84]. For instance, cells infected with pathogenic bacteria or viruses undergo pyroptosis induced by activation of inflammasome sensors, resulting in the loss of plasma membrane integrity, leakage of cellular contents, and inflammation [85]. Inflammation can be further classified as either acute inflammation which occurs immediately after injury and lasts for few days or chronic inflammation which may last for several months or sometimes even years. During acute inflammatory responses, the body efficiently minimizes impending damage by removing injurious stimuli and initiating the healing process. This leads to the restoration of tissue homeostasis and the resolution of inflammation [86]. Another form of cell death known as pyroptosis has been long studied for its role in chronic inflammatory diseases, such as Alzheimer's disease $[87,88]$ and atherosclerosis [89]. Under chronic conditions, the inflammation fails to resolve due to excessive and uncontrollable activity of the immune system which can lead to extensive tissue damage [90]. Hence, new therapies aimed at preventing this hyperactivity of the immune system could have major clinical benefits.

Recently EVs have gained attention as mediators and biomarkers of inflammation (Table 3). The discovery of MHC harboring EVs shed by multiple lineages of immune cells suggested a complex functional role for these vesicles as they mediated antigen specific immune response $[34,91,92]$. Further, secretion of tumor growth factor $\beta 1$ via EVs was found to modulate anti-inflammatory effects [93]. ApoExos containing Sphingosine 1-Phosphate Receptors 1 and SPR1/3 have been identified to induce proinflammatory cytokine production in macrophages leading to activation of NF-kB and p38 MAPK [37]. Non-coding RNAs delivered via ApoExos have been found to be pro-inflammatory in nature as they stimulate toll-like receptors [94]. Additionally, EVs have been found to contain wide variety of proteins, including chemokines and inflammatory cytokines, such as tumor necrosis factor (TNF), IL-1 $\beta$, CXCL2, and CXCL8 suggesting an important immune modulatory functions of EVs [95-97]. In the following section, we aim to discuss existing literature with the focus on the role of EVs during acute inflammation in diseases, such as sepsis and ARDS, and chronic inflammation associated with diseases, such as COPD and asthma.

Table 3. Table summarizing studies with a role for EVs in mediating inflammation sepsis and lung disorders. NS-not specified in the original article.

\begin{tabular}{ccccc}
\hline Cargo & EV Source & Identified in & Function & Reference \\
\hline MHC & $\begin{array}{c}\text { Dendritic cells, B } \\
\text { lymphocytes }\end{array}$ & NS & $\begin{array}{c}\text { antigen specific } \\
\text { immune response }\end{array}$ & {$[34,91,92]$} \\
\hline NS & Neutrophils & NS & anti-inflammatory effects & {$[93]$} \\
\hline
\end{tabular}


Table 3. Cont.

\begin{tabular}{|c|c|c|c|c|}
\hline Cargo & EV Source & Identified in & Function & Reference \\
\hline $\begin{array}{c}\text { Sphingosine } \\
\text { 1-Phosphate Receptors } \\
1 \text { and SPR1/3 }\end{array}$ & $\begin{array}{c}\text { Bone } \\
\text { marrow-derived } \\
\text { macrophages }\end{array}$ & NS & pro-inflammatory effects & [37] \\
\hline Non-coding RNA & Endothelial cells & NS & pro-inflammatory effects & [94] \\
\hline $\begin{array}{l}\text { Chemokines and } \\
\text { inflammatory } \\
\text { cytokines: TNF, IL-1 } \beta \text {, } \\
\text { CXCL2, CXCL8 }\end{array}$ & $\begin{array}{l}\text { Dendritic cells, } \\
\text { Mesenchymal } \\
\text { stromal cells }\end{array}$ & NS & $\begin{array}{l}\text { immune modulatory } \\
\text { functions }\end{array}$ & [95-97] \\
\hline $\begin{array}{l}\text { Bacterial virulence } \\
\text { factors }\end{array}$ & Bacteria & Sepsis & pro-inflammatory effects & [98] \\
\hline Nef protein & $\begin{array}{l}\text { HIV type } 1 \\
\text { infected cells }\end{array}$ & $\begin{array}{l}\text { HIV type } 1 \\
\text { infection }\end{array}$ & anti-inflammatory effects & [99] \\
\hline NS & $\begin{array}{c}\text { platelets, } \\
\text { granulocytes }\end{array}$ & $\begin{array}{l}\text { Meningococcal } \\
\text { sepsis }\end{array}$ & pro-coagulation activity & [100] \\
\hline $\begin{array}{l}\text { IL-12, IL-15, } \\
\text { IL-17, IFN- } \gamma\end{array}$ & NS & sepsis & pro-inflammatory effects & {$[101,102]$} \\
\hline IL-4, IL-10 & NS & sepsis & anti-inflammatory effects & {$[101,102]$} \\
\hline Adhesion molecules & $\begin{array}{l}\text { activated } \\
\text { polymorphonuclear } \\
\text { leukocytes }\end{array}$ & sepsis & organ damage & {$[103,104]$} \\
\hline NS & platelet & sepsis & pro-apoptotic & [105] \\
\hline miR-103-3p & $\begin{array}{c}\text { activated } \\
\text { macrophages }\end{array}$ & sepsis & organ damage & [106] \\
\hline NS & granulocyte & sepsis & anti-bacterial effects & [107] \\
\hline NS & & sepsis & $\begin{array}{c}\text { protecting from } \\
\text { vascular dysfunction }\end{array}$ & [108] \\
\hline alpha-2-macroglobulin & granulocytes & sepsis & $\begin{array}{c}\text { bacterial clearance, } \\
\text { anti-inflammatory effects }\end{array}$ & [109] \\
\hline NS & $\begin{array}{c}\text { Immature } \\
\text { dendritic cells }\end{array}$ & sepsis & anti-inflammatory effects & [110] \\
\hline $\begin{array}{c}\text { membrane } \\
\text { tethered mucins }\end{array}$ & Lung epithelial cells & - & innate defense & [111] \\
\hline SOCS1 and 3 & $\begin{array}{c}\text { Alveolar } \\
\text { macrophages }\end{array}$ & $\begin{array}{l}\text { cigarette smoke } \\
\text { exposure }\end{array}$ & $\begin{array}{c}\text { modulation of } \\
\text { inflammatory signalling }\end{array}$ & [112] \\
\hline CCN1 & lung epithelial cells & COPD & pro-inflammatory effects & [113] \\
\hline NS & lung epithelial cells & Asthma & pro-inflammatory effects & [114] \\
\hline $\begin{array}{l}\text { MHC class II, CD86, } \\
\text { LFA- } 1 \text { and ICAM-1 }\end{array}$ & mast cells & Asthma & pro-inflammatory effects & [115] \\
\hline FceRI & mast cells & Asthma & anti-inflammatory effects & [116] \\
\hline NS & eosinophils & Asthma & pro-inflammatory effects & {$[79,117]$} \\
\hline NS & Dendritic cells & NS & pro-inflammatory effects & [118] \\
\hline NS & B cell & Allergy & pro-inflammatory effects & [119] \\
\hline Caspase-1 & $\begin{array}{c}\text { activated } \\
\text { macrophages }\end{array}$ & NS & pro-apoptotic & [81] \\
\hline ACE2, CD9 & $\begin{array}{l}\text { SARS-CoV-2 } \\
\text { infected cells }\end{array}$ & COVID-19 & promote infection & [120] \\
\hline NS & NS & COVID-19 & pro-coagulation activity & {$[121,122]$} \\
\hline NS & $\begin{array}{l}\text { mesenchymal } \\
\text { stem cells }\end{array}$ & NS & anti-inflammatory & [123] \\
\hline
\end{tabular}

\section{EVs in Sepsis Associated Inflammation}

Sepsis is a dysregulated systemic inflammatory disorder that can lead to life threatening organ injury [124]. Since their discovery over two decades ago, Evs originating from 
different type of cells have been shown to play diverse roles in sepsis. The source of Evs during sepsis can be either from the pathogen responsible for the infection or the host's own cells [125].

Cell death is the most common outcome during infections. Pathogen can trigger both non-inflammatory modes of cell death, such as apoptosis and autophagy or inflammatory modes of cell death, such as pyroptosis and oncosis [126]. Gram-positive and Gramnegative bacteria, as the most frequent infectious agent of sepsis, can produce EVs [127] that carry bacterial virulence factors that contribute towards the systemic inflammation [98]. During sepsis, lymphocytes are depleted by apoptosis, which leads to immunosuppression [128]. Exosomes from HIV type 1 infected cells has been shown to contain the accessory extracellular viral protein Nef, which was shown to induce apoptosis of CD4 ${ }^{+}$T-cells [99]. Given that pathogen-derived EVs carry cargo that are representative of their cell of origin, bacterial protoplast-derived nanovesicles have been used to vaccinate mice against these pathogens in models of pneumonia and peritonitis [129].

On the other hand, host-derived EVs during sepsis are produced mainly from immune cells such as platelets and innate immune cells [125]. Increased levels of platelet MVs has been observed in patients with Gram-negative bacterial sepsis [130]. MVs originating from platelets or granulocytes were also elevated in meningococcal sepsis [100]. These MVs were associated with increased coagulation activity. Consequently, MVs have also been linked with thromboembolic events and in patients with transient ischemic attacks, lacunar infarcts and multi-infarct dementias have elevated levels of MVs [131-133]. Hence, hostderived MVs have been suggested as a novel target for therapeutic intervention in clinical conditions with enhanced coagulation activation [100]. In sepsis neutrophils are one of the vital leukocytes to play first line of defense [134-136]. Neutrophil-derived EVs dramatically increased in the blood of mice subjected to cecal ligation and puncture (CLP), a commonly used animal model of sepsis [137]. Treatment with neutral sphingomyelinase inhibitor, GW4869 which blocks exosome production, significantly improved the survival of mice subjected to LPS injection or CLP, suggesting that exosomes might play an important role in sepsis [138]. Studies have also shown altered contents and function of host derived EVs during sepsis. In sepsis, exosomes carry increased levels of cytokines and damageassociated molecular patters (DAMPS) to induce inflammation. It is well documented that patients with sepsis have increased levels of serum cytokines which are important for initiation of the "cytokine storm". Exosomes have been shown to carry biologically active pro-inflammatory cytokines IL-12, IL-15, IL-17, and IFN- $\gamma$ at early phase and antiinflammatory cytokines, IL-4 and IL-10 at late phase of the cytokine storm [101,102].

EVs play major roles in organ damage during sepsis. Activated polymorphonuclear leukocytes from septic patients have been shown to produce microparticles with increased adhesion molecules that can activate the vascular endothelium leading to endothelial injury and resultant organ dysfunction [103,104]. Moreover, platelet-derived exosomes from sepsis patients induced apoptosis of endothelial cells and vascular smooth muscle cells due to increased NADPH activity and by generating reactive oxygen species, such as superoxide, nitric oxide, and peroxynitrite [105]. Thereby, exosomes have been implicated in the induction of oxidative stress and myocardial dysfunction and vascular cell apoptosis. Additionally, exosomes have also been shown to contribute to septic encephalopathy directly and by causing systemic immune dysfunction due to the collapse of neuroendocrine immune networks [139]. Lastly, exosomes may contribute to chronic liver dysfunction after sepsis, as exosomal miR-103-3p from LPS-activated macrophages targeted KLF4 to increase liver fibrosis [106].

The role of EVs in sepsis may not be limited to causing damage to host cells and organs. Interestingly, several protective host EV-related mechanisms were recently discovered in sepsis models. In several studies, granulocyte derived EVs have shown antibacterial effects [107] in addition to supporting the production of inflammatory mediators and protecting from vascular dysfunction [108]. Likewise, EVs containing alpha-2-macroglobulin excreted by neutrophilic granulocytes were shown to help in bacterial clearance and reduce 
inflammation in a mouse model of sepsis [109]. Immature dendritic cell-derived exosomes attenuated the acute systemic inflammatory response in sepsis by enhancing apoptotic cell clearance in septic rats [110]. Overall, EVs have both protective and detrimental roles during sepsis in a contextual manner, depending on their cell type of origin and the cargo contained within [125]. In this context, the protein cargo from EVs isolated from the serum of patients following sepsis diagnosis has been analyzed in a clinical study to identify biomarkers for better disease management and monitoring disease progress and prognosis [140]. Further knowledge from similar studies will be instrumental in developing novel therapeutic interventions and even biomarker discovery for improved management of sepsis patients.

Lung is one of the most susceptible organs to systemic inflammation. Septic patients are often accompanied by ALI or ARDS, which further add to sepsis-associated mortality [141]. Thus, in the following section we discuss the role of EVs in lung inflammation.

\section{EVs in Lung Inflammatory Disorders}

Lung is the organ with highest vascular density in the human body. Hence, the endothelium of the lung contributes substantially to the circulation of EVs which, in turn, play critical roles in normal lung physiology [142]. Lung epithelial cell-derived exosomes contain membrane-tethered mucins that contribute to the innate defense of the airway [111]. EVs have also gained attention as novel communicators in lung diseases, such as COPD, asthma, ALI, and ARDS [143]. Alveolar macrophages can secrete SOCS1 and 3 (suppressor of cytokine signaling 1,3) in EVs which can further control inflammatory signaling. This process has been observed to be dysregulated in association with cigarette smoke exposure [112]. EV secretion from lung endothelial cells is enhanced during adverse conditions, such as infection and smoke exposure $[144,145]$. These vesicles are primarily generated by an apoptosis-dependent mechanism that is triggered upon pulmonary endothelial damage. Circulating lung endothelial cell-derived EVs can, therefore, be potential biomarkers for lung injury and inflammation. In one such study, cigarette smoke extract induced CCN1enriched exosomes. $\mathrm{CCN} 1$ is generally known to play crucial roles in tissue remodeling and repair as an early response gene product and as an extracellular matrix protein $[146,147]$. However, these exosomes were found to induce the activation of IL-8 secretion which recruits inflammatory cells, particularly neutrophils, into the lung parenchyma, further promoting lung inflammation in COPD [113].

Enhanced secretion of exosomes by lung epithelial cells has also been observed in asthma which is a chronic, recurrent, and incurable allergy-related respiratory disease. These epithelial cell-derived exosomes induced proliferation and chemotaxis of undifferentiated macrophages and inhibition of exosome production, which resulted in a reduced population of proliferating monocytes and alleviation of various asthmatic features [114]. Asthma is characterized by the infiltration of airway with $\mathrm{T}$ lymphocytes, mast cells, basophils, macrophages, and eosinophils [148]. Mast cells secrete exosomes that carry immunologically relevant molecules, such as MHC class II, CD86, LFA-1, and ICAM-1. These exosomes can act as messengers to induce splenic $B$ and $T$ cell blast activation and have been suggested to play a role in the recruitment of these cells to the lungs, eventually contributing to lung inflammation [115]. On the contrary, mast cell exosomes containing high-affinity IgE receptors ( $\left.F_{c} \varepsilon R I\right)$ have been shown to suppress allergic reactions by binding to free IgE [116]. Eosinophils are the main effector cells in asthma. Eosinophils of asthmatic patients were shown to produce more exosomes than those of healthy individuals and these exosomes promoted inflammatory behavior of eosinophils that is related to asthma pathogenesis $[79,117]$. Similarly, dendritic cell and B cell-derived exosomes have been shown to play a role in stimulating the allergic immune response via stimulation of $\mathrm{T}$ cell proliferation and induction of cytokine production of allergen-specific T cells (IL-4, IL-5, and IL-13 and lower levels of IFN- $\gamma$ and TNF- $\alpha$ ) [118,119].

ALI and ARDS remain as life-threatening diseases in critically ill patients. ALI and ARDS can be triggered by both non-infectious (sterile) and infectious stimuli underly- 
ing clinical disorders, such as sepsis, pneumonia, trauma, and pancreatitis [149-151]. Studies have shown that proceeding sterile stimuli, alveolar type-I epithelial cells were the main source of the EVs in the bronchoalveolar lavage fluid (BALF) whereas infectious stimuli-induced BALF EVs were mainly derived from alveolar macrophages. Both sterile stimuli-induced EVs and infection-induced EVs facilitated classic macrophage activation, and subsequently promoted inflammatory lung responses via different signaling pathways [152]. Caspase-1 encapsulated in exosomes released from LPS-challenged macrophages induced lung endothelial cell apoptosis, indicating their contribution to the disruption of the alveolar-capillary barrier [81]. Given the ability of EVs to induce an inflammatory response and cell death of lung tissue, they have the potential to be targeted for more effective therapeutic approaches to treat ALI and ARDS [153].

The novel coronavirus disease (COVID-19) is responsible for millions of deaths worldwide with the respiratory failure been the most common clinical presentation [154]. Recent evidence points to a correlation between COVID-19 severity and pyroptotic inflammasome activation by SARS-CoV-2 infection [155]. COVID-19 can cause lung complications, such as pneumonia, and in the most severe cases ARDS and sepsis [156]. In a recent proteomic analysis of COVID-19 patient-derived exosomes, several molecules were identified which are involved in several biological processes. These processes include immune response, inflammation, and activation of the coagulation and complement pathways, the main mechanisms of COVID-19-associated tissue damage and multiple organ dysfunctions. Several potential biomarkers, such as fibrinogen, fibronectin, complement $\mathrm{C} 1 \mathrm{r}$ subcomponent, and serum amyloid P-component that are well correlated with the COVID-19 disease's severity were also encapsulated within these exosomes [157]. The presence of viral material amongst the exosomal cargo showed that SARS-CoV-2 could use the cell-to-cell communication system to spread infection in the host $[120,157]$. Cells that express ACE2 and CD9 can transfer these viral receptors to other cells via EVs, making recipient cells more susceptible for SARS-CoV2 infection [120]. GM3-enriched exosomes were shown to be positively correlated with COVID-19 disease severity, suggesting they may partake in pathological processes related to COVID-19 pathogenesis [158]. In SARS-CoV-2 infection, the systemic inflammatory response was shown to result in the release of substantial amounts of procoagulant EVs that may act as clotting initiation agents, contributing to disease severity [121,122]. On the other hand, exosome-based strategies were also proposed to treat COVID-19 or prevent SARS-CoV-2 infection [120,123,159]. Especially, MSCs-derived EVs from a broad range of sources, including bone marrow, adipose tissue, umbilical cord are currently under investigation for many conditions and areas of regenerative medicine [160]. They have been shown to alleviate severe inflammation (cytokine storm) and repair damaged lung cells in COVID-19 by delivery of anti-inflammatory molecules. There are several ongoing clinical trials that apply these therapeutically beneficial EVs for treatment of COVID-19 patients as drug delivery platforms or vaccines [154,161,162]. Therefore, similarly to sepsis, EVs from diverse sources exhibit distinct effects during COVID-19 infections [163].

\section{Conclusions}

Overall, there is strong evidence to support the significance of EVs in the modulation of inflammation and cell death and the diseases related to these processes. EVs have been shown to play critical roles in both promoting and suppressing cell death and inflammation leading to beneficial, as well as detrimental, health outcomes. Over the last couple of decades, studies on EVs have shown their great potential to improve diagnosis and therapy in human diseases. As has been occasionally discussed in this article as well, EVs present as a valuable target for disease treatment, targeted drug-delivery, vaccine development and biomarker discovery. Furthermore, there is a need for developing better methods for isolation of pure EV subtypes and address the challenge of EV heterogeneity in preparations. The establishment of precise isolation methods is crucial before a particular function can be attributed to any specific EV subtype. Further, MSC-derived EVs are widely explored in preclinical and clinical settings due to their therapeutic potential. However, translation of 
such findings regarding EVs to clinical practices would require further exploration of their exact mode of biogenesis and cargo components, which are responsible for the desired phenotype to clearly understand the underlying mode of action. Despite these knowledge gaps and shortcomings, with further exploration employing improved methodologies and techniques, EVs remain as putative therapeutic targets for the future.

Author Contributions: L.G. planned the review. L.G. and R.S. contributed to the writing and editing of the review. R.S. prepared the figures. All authors have read and agreed to the published version of the manuscript.

Funding: This research received no external funding.

Institutional Review Board Statement: Not applicable.

Informed Consent Statement: Not applicable.

Acknowledgments: The authors would like to thank Christina Nedeva for valuable feedback and help in formatting the manuscript.

Conflicts of Interest: The authors declare no conflict of interest.

\section{Abbreviations}

$\begin{array}{ll}\text { ALI } & \text { Acute lung injury } \\ \text { ApoBDs } & \text { Apoptotic bodies } \\ \text { ApoEVs } & \text { Apoptotic EVs } \\ \text { ApoExos } & \text { Apoptotic exosomes } \\ \text { ApoMVs } & \text { Apoptotic microvesicles } \\ \text { ARDS } & \text { Acute respiratory distress syndrome } \\ \text { BALF } & \text { Bronchoalveolar lavage fluid } \\ \text { CD } & \text { Cluster of differentiation } \\ \text { CLP } & \text { Cecal ligation and puncture } \\ \text { COPD } & \text { Chronic obstructive pulmonary disorder } \\ \text { EVs } & \text { Extracellular vesicles } \\ \text { HSP HIV } & \text { Heat shock protein Human immunodeficiency virus } \\ \text { IECs } & \text { Intestinal epithelial cells } \\ \text { LPS } & \text { Lipopolysaccharide } \\ \text { MEVs } & \text { Milk-derived EVs } \\ \text { MHC } & \text { Major histocompatibility complex } \\ \text { miR } & \text { micro-RNA } \\ \text { MSCs } & \text { Mesenchymal stem cells } \\ \text { MVB } & \text { Multivesicular bodies } \\ \text { MVs } & \text { Microvesicles } \\ \text { PAMPs } & \text { Pathogen associated molecular patters } \\ \text { TNF } & \text { Tumor necrosis factor }\end{array}$

\section{References}

1. Kalra, H.; Drummen, G.P.C.; Mathivanan, S. Focus on Extracellular Vesicles: Introducing the Next Small Big Thing. Int. J. Mol. Sci. 2016, 17, 170. [CrossRef]

2. Harding, C.; Heuser, J.; Stahl, P. Endocytosis and intracellular processing of transferrin and colloidal gold-transferrin in rat reticulocytes: Demonstration of a pathway for receptor shedding. Eur. J. Cell Biol. 1984, 35, 256-263.

3. Pan, B.T.; Teng, K.; Wu, C.; Adam, M.; Johnstone, R.M. Electron microscopic evidence for externalization of the transferrin receptor in vesicular form in sheep reticulocytes. J. Cell Biol. 1985, 101, 942-948. [CrossRef]

4. Gangoda, L.; Boukouris, S.; Liem, M.; Kalra, H.; Mathivanan, S. Extracellular vesicles including exosomes are mediators of signal transduction: Are they protective or pathogenic? Proteomics 2015, 15, 260-271. [CrossRef]

5. Raposo, G.; Stoorvogel, W. Extracellular vesicles: Exosomes, microvesicles, and friends. J. Cell Biol. 2013, 200, 373-383. [CrossRef] [PubMed]

6. Kalluri, R. The biology and function of exosomes in cancer. J. Clin. Investig. 2016, 126, 1208-1215. [CrossRef] [PubMed]

7. Howitt, J.; Hill, A.F. Exosomes in the Pathology of Neurodegenerative Diseases. J. Biol. Chem. 2016, 291, 26589-26597. [CrossRef] [PubMed] 
8. Samuel, M.; Fonseka, P.; Sanwlani, R.; Gangoda, L.; Chee, S.H.; Keerthikumar, S.; Spurling, A.; Chitti, S.V.; Zanker, D.; Ang, C.-S.; et al. Oral administration of bovine milk-derived extracellular vesicles induces senescence in the primary tumor but accelerates cancer metastasis. Nat. Commun. 2021, 12, 3950. [CrossRef]

9. Sanwlani, R.; Fonseka, P.; Chitti, S.V.; Mathivanan, S. Milk-Derived Extracellular Vesicles in Inter-Organism, Cross-Species Communication and Drug Delivery. Proteomes 2020, 8, 11. [CrossRef]

10. Sanwlani, R.; Fonseka, P.; Mathivanan, S. Are Dietary Extracellular Vesicles Bioavailable and Functional in Consuming Organisms? Subcell. Biochem. 2021, 97, 509-521. [CrossRef]

11. Kang, T.; Atukorala, I.; Mathivanan, S. Biogenesis of Extracellular Vesicles. Subcell. Biochem. 2021, 97, 19-43. [CrossRef] [PubMed]

12. Théry, C.; Zitvogel, L.; Amigorena, S. Exosomes: Composition, biogenesis and function. Nat. Rev. Immunol. 2002, 2, 569-579. [CrossRef]

13. Keerthikumar, S.; Gangoda, L.; Liem, M.; Fonseka, P.; Atukorala, I.; Ozcitti, C.; Mechler, A.; Adda, C.G.; Ang, C.S.; Mathivanan, S. Proteogenomic analysis reveals exosomes are more oncogenic than ectosomes. Oncotarget 2015, 6, 15375-15396. [CrossRef]

14. Zhang, H.; Freitas, D.; Kim, H.S.; Fabijanic, K.; Li, Z.; Chen, H.; Mark, M.T.; Molina, H.; Martin, A.B.; Bojmar, L.; et al. Identification of distinct nanoparticles and subsets of extracellular vesicles by asymmetric flow field-flow fractionation. Nat. Cell Biol. 2018, 20, 332-343. [CrossRef] [PubMed]

15. Anand, S.; Samuel, M.; Mathivanan, S. Exomeres: A New Member of Extracellular Vesicles Family. In New Frontiers: Extracellular Vesicles; Mathivanan, S., Fonseka, P., Nedeva, C., Atukorala, I., Eds.; Springer International Publishing: Cham, Switzerland, 2021; pp. 89-97.

16. György, B.; Szabó, T.G.; Pásztói, M.; Pál, Z.; Misják, P.; Aradi, B.; László, V.; Pállinger, E.; Pap, E.; Kittel, A.; et al. Membrane vesicles, current state-of-the-art: Emerging role of extracellular vesicles. Cell. Mol. Life Sci. CMLS 2011, 68, 2667-2688. [CrossRef]

17. Minciacchi, V.R.; You, S.; Spinelli, C.; Morley, S.; Zandian, M.; Aspuria, P.-J.; Cavallini, L.; Ciardiello, C.; Reis Sobreiro, M.; Morello, M.; et al. Large oncosomes contain distinct protein cargo and represent a separate functional class of tumor-derived extracellular vesicles. Oncotarget 2015, 6, 11327-11341. [CrossRef] [PubMed]

18. Zijlstra, A.; Di Vizio, D. Size matters in nanoscale communication. Nat. Cell Biol. 2018, 20, 228-230. [CrossRef]

19. Tavano, S.; Heisenberg, C.-P. Migrasomes take center stage. Nat. Cell Biol. 2019, 21, 918-920. [CrossRef]

20. Atkin-Smith, G.K.; Tixeira, R.; Paone, S.; Mathivanan, S.; Collins, C.; Liem, M.; Goodall, K.J.; Ravichandran, K.S.; Hulett, M.D.; Poon, I.K.H. A novel mechanism of generating extracellular vesicles during apoptosis via a beads-on-a-string membrane structure. Nat. Commun. 2015, 6, 7439. [CrossRef] [PubMed]

21. Kerr, J.F.R.; Wyllie, A.H.; Currie, A.R. Apoptosis: A Basic Biological Phenomenon with Wideranging Implications in Tissue Kinetics. Br. J. Cancer 1972, 26, 239-257. [CrossRef]

22. Kakarla, R.; Hur, J.; Kim, Y.J.; Kim, J.; Chwae, Y.-J. Apoptotic cell-derived exosomes: Messages from dying cells. Exp. Mol. Med. 2020, 52, 1-6. [CrossRef] [PubMed]

23. Schiller, M.; Parcina, M.; Heyder, P.; Foermer, S.; Ostrop, J.; Leo, A.; Heeg, K.; Herrmann, M.; Lorenz, H.-M.; Bekeredjian-Ding, I. Induction of Type I IFN Is a Physiological Immune Reaction to Apoptotic Cell-Derived Membrane Microparticles. J. Immunol. 2012, 189, 1747-1756. [CrossRef] [PubMed]

24. Tucher, C.; Bode, K.; Schiller, P.; Claßen, L.; Birr, C.; Souto-Carneiro, M.M.; Blank, N.; Lorenz, H.-M.; Schiller, M. Extracellular Vesicle Subtypes Released from Activated or Apoptotic T-Lymphocytes Carry a Specific and Stimulus-Dependent Protein Cargo. Front. Immunol. 2018, 9, 534. [CrossRef] [PubMed]

25. Sirois, I.; Raymond, M.A.; Brassard, N.; Cailhier, J.F.; Fedjaev, M.; Hamelin, K.; Londono, I.; Bendayan, M.; Pshezhetsky, A.V.; Hébert, M.J. Caspase-3-dependent export of TCTP: A novel pathway for antiapoptotic intercellular communication. Cell Death Differ. 2011, 18, 549-562. [CrossRef] [PubMed]

26. Sirois, I.; Groleau, J.; Pallet, N.; Brassard, N.; Hamelin, K.; Londono, I.; Pshezhetsky, A.V.; Bendayan, M.; Hébert, M.J. Caspase activation regulates the extracellular export of autophagic vacuoles. Autophagy 2012, 8, 927-937. [CrossRef]

27. Pathan, M.; Fonseka, P.; Chitti, S.V.; Kang, T.; Sanwlani, R.; Van Deun, J.; Hendrix, A.; Mathivanan, S. Vesiclepedia 2019: A compendium of RNA, proteins, lipids and metabolites in extracellular vesicles. Nucleic Acids Res. 2019, 47, D516-D519. [CrossRef]

28. Mori, Y.; Koike, M.; Moriishi, E.; Kawabata, A.; Tang, H.; Oyaizu, H.; Uchiyama, Y.; Yamanishi, K. Human Herpesvirus-6 Induces MVB Formation, and Virus Egress Occurs by an Exosomal Release Pathway. Traffic 2008, 9, 1728-1742. [CrossRef]

29. Kalra, H.; Gangoda, L.; Fonseka, P.; Chitti, S.V.; Liem, M.; Keerthikumar, S.; Samuel, M.; Boukouris, S.; Al Saffar, H.; Collins, C.; et al. Extracellular vesicles containing oncogenic mutant $\beta$-catenin activate Wnt signalling pathway in the recipient cells. $J$. Extracell. Vesicles 2019, 8, 1690217. [CrossRef]

30. Chen, G.; Huang, A.C.; Zhang, W.; Zhang, G.; Wu, M.; Xu, W.; Yu, Z.; Yang, J.; Wang, B.; Sun, H.; et al. Exosomal PD-L1 contributes to immunosuppression and is associated with anti-PD-1 response. Nature 2018, 560, 382-386. [CrossRef]

31. Boukouris, S.; Mathivanan, S. Exosomes in bodily fluids are a highly stable resource of disease biomarkers. Proteomics. Clin. Appl. 2015, 9, 358-367. [CrossRef]

32. Mathivanan, S.; Lim, J.W.E.; Tauro, B.J.; Ji, H.; Moritz, R.L.; Simpson, R.J. Proteomics Analysis of A33 Immunoaffinity-purified Exosomes Released from the Human Colon Tumor Cell Line LIM1215 Reveals a Tissue-specific Protein Signature. Mol. Cell. Proteom. 2010, 9, 197-208. [CrossRef] [PubMed]

33. Srivastava, P. Interaction of Heat Shock Proteins with Peptides and Antigen Presenting Cells: Chaperoning of the Innate and Adaptive Immune Responses. Annu. Rev. Immunol. 2002, 20, 395-425. [CrossRef] [PubMed] 
34. Théry, C.; Ostrowski, M.; Segura, E. Membrane vesicles as conveyors of immune responses. Nat. Rev. Immunol. 2009,9 , 581-593. [CrossRef] [PubMed]

35. Borges, F.T.; Reis, L.A.; Schor, N. Extracellular vesicles: Structure, function, and potential clinical uses in renal diseases. Braz. J. Med. Biol. Res. Rev. Bras. Pesqui. Med. E Biol. 2013, 46, 824-830. [CrossRef] [PubMed]

36. Poon, I.K.; Lucas, C.D.; Rossi, A.G.; Ravichandran, K.S. Apoptotic cell clearance: Basic biology and therapeutic potential. Nat. Rev. Immunol. 2014, 14, 166-180. [CrossRef] [PubMed]

37. Park, S.J.; Kim, J.M.; Kim, J.; Hur, J.; Park, S.; Kim, K.; Shin, H.J.; Chwae, Y.J. Molecular mechanisms of biogenesis of apoptotic exosome-like vesicles and their roles as damage-associated molecular patterns. Proc. Natl. Acad. Sci. USA 2018, 115, E11721-E11730. [CrossRef]

38. Valadi, H.; Ekström, K.; Bossios, A.; Sjöstrand, M.; Lee, J.J.; Lötvall, J.O. Exosome-mediated transfer of mRNAs and microRNAs is a novel mechanism of genetic exchange between cells. Nat. Cell Biol. 2007, 9, 654-659. [CrossRef]

39. Kalluri, R.; LeBleu, V.S. Discovery of Double-Stranded Genomic DNA in Circulating Exosomes. Cold Spring Harb. Symp. Quant. Biol. 2016, 81, 275-280. [CrossRef]

40. Kurywchak, P.; Kalluri, R. An evolving function of DNA-containing exosomes in chemotherapy-induced immune response. Cell Res. 2017, 27, 722-723. [CrossRef]

41. Llorente, A.; Skotland, T.; Sylvänne, T.; Kauhanen, D.; Róg, T.; Orłowski, A.; Vattulainen, I.; Ekroos, K.; Sandvig, K. Molecular lipidomics of exosomes released by PC-3 prostate cancer cells. Biochim. Biophys. Acta Mol. Cell Biol. Lipids 2013, 1831, 1302-1309. [CrossRef]

42. Lydic, T.A.; Townsend, S.; Adda, C.G.; Collins, C.; Mathivanan, S.; Reid, G.E. Rapid and comprehensive 'shotgun' lipidome profiling of colorectal cancer cell derived exosomes. Methods 2015, 87, 83-95. [CrossRef] [PubMed]

43. Skotland, T.; Sandvig, K.; Llorente, A. Lipids in exosomes: Current knowledge and the way forward. Prog. Lipid Res. 2017, 66, 30-41. [CrossRef] [PubMed]

44. Kim, C.W.; Lee, H.M.; Lee, T.H.; Kang, C.; Kleinman, H.K.; Gho, Y.S. Extracellular Membrane Vesicles from Tumor Cells Promote Angiogenesis via Sphingomyelin. Cancer Res. 2002, 62, 6312-6317. [PubMed]

45. Galluzzi, L.; Vitale, I.; Aaronson, S.A.; Abrams, J.M.; Adam, D.; Agostinis, P.; Alnemri, E.S.; Altucci, L.; Amelio, I.; Andrews, D.W.; et al. Molecular mechanisms of cell death: Recommendations of the Nomenclature Committee on Cell Death 2018. Cell Death Differ. 2018, 25, 486-541. [CrossRef] [PubMed]

46. Reinhardt, T.A.; Sacco, R.E.; Nonnecke, B.J.; Lippolis, J.D. Bovine milk proteome: Quantitative changes in normal milk exosomes, milk fat globule membranes and whey proteomes resulting from Staphylococcus aureus mastitis. J. Proteom. 2013, 82, 141-154. [CrossRef]

47. Miyake, H.; Lee, C.; Chusilp, S.; Bhalla, M.; Li, B.; Pitino, M.; Seo, S.; O'Connor, D.L.; Pierro, A. Human breast milk exosomes attenuate intestinal damage. Pediatric Surg. Int. 2020, 36, 155-163. [CrossRef] [PubMed]

48. Chen, T.; Xie, M.-Y.; Sun, J.-J.; Ye, R.-S.; Cheng, X.; Sun, R.-P.; Wei, L.-M.; Li, M.; Lin, D.-L.; Jiang, Q.-Y.; et al. Porcine milk-derived exosomes promote proliferation of intestinal epithelial cells. Sci. Rep. 2016, 6, 33862. [CrossRef]

49. Gao, H.N.; Guo, H.Y.; Zhang, H.; Xie, X.L.; Wen, P.C.; Ren, F.Z. Yak-milk-derived exosomes promote proliferation of intestinal epithelial cells in an hypoxic environment. J. Dairy Sci. 2019, 102, 985-996. [CrossRef]

50. Martin, C.; Patel, M.; Williams, S.; Arora, H.; Brawner, K.; Sims, B. Human breast milk-derived exosomes attenuate cell death in intestinal epithelial cells. Innate Immun. 2018, 24, 278-284. [CrossRef]

51. Melnik, B.C.; Schmitz, G. Milk's Role as an Epigenetic Regulator in Health and Disease. Diseases 2017, 5, 12. [CrossRef] [PubMed]

52. Meng, F.; Henson, R.; Wehbe-Janek, H.; Ghoshal, K.; Jacob, S.T.; Patel, T. MicroRNA-21 Regulates Expression of the PTEN Tumor Suppressor Gene in Human Hepatocellular Cancer. Gastroenterology 2007, 133, 647-658. [CrossRef]

53. Murata, T.; Takayama, K.; Katayama, S.; Urano, T.; Horie-Inoue, K.; Ikeda, K.; Takahashi, S.; Kawazu, C.; Hasegawa, A.; Ouchi, Y.; et al. miR-148a is an androgen-responsive microRNA that promotes LNCaP prostate cell growth by repressing its target CAND1 expression. Prostate Cancer Prostatic Dis. 2010, 13, 356-361. [CrossRef]

54. Fonseka, P.; Liem, M.; Ozcitti, C.; Adda, C.G.; Ang, C.-S.; Mathivanan, S. Exosomes from N-Myc amplified neuroblastoma cells induce migration and confer chemoresistance to non-N-Myc amplified cells: Implications of intra-tumour heterogeneity. J. Extracell. Vesicles 2019, 8, 1597614. [CrossRef] [PubMed]

55. Pavlyukov, M.S.; Yu, H.; Bastola, S.; Minata, M.; Shender, V.O.; Lee, Y.; Zhang, S.; Wang, J.; Komarova, S.; Wang, J.; et al. Apoptotic Cell-Derived Extracellular Vesicles Promote Malignancy of Glioblastoma Via Intercellular Transfer of Splicing Factors. Cancer Cell 2018, 34, 119-135.e110. [CrossRef] [PubMed]

56. Gallet, R.; Dawkins, J.; Valle, J.; Simsolo, E.; de Couto, G.; Middleton, R.; Tseliou, E.; Luthringer, D.; Kreke, M.; Smith, R.R.; et al. Exosomes secreted by cardiosphere-derived cells reduce scarring, attenuate adverse remodelling, and improve function in acute and chronic porcine myocardial infarction. Eur. Heart J. 2017, 38, 201-211. [CrossRef]

57. Zhao, G.; Liu, F.; Liu, Z.; Zuo, K.; Wang, B.; Zhang, Y.; Han, X.; Lian, A.; Wang, Y.; Liu, M.; et al. MSC-derived exosomes attenuate cell death through suppressing AIF nucleus translocation and enhance cutaneous wound healing. Stem Cell Res. Ther. 2020, 11, 174. [CrossRef] [PubMed]

58. Wang, Y.; Zhang, L.; Li, Y.; Chen, L.; Wang, X.; Guo, W.; Zhang, X.; Qin, G.; He, S.H.; Zimmerman, A.; et al. Exosomes/microvesicles from induced pluripotent stem cells deliver cardioprotective miRNAs and prevent cardiomyocyte apoptosis in the ischemic myocardium. Int. J. Cardiol. 2015, 192, 61-69. [CrossRef] [PubMed] 
59. Liu, L.; Jin, X.; Hu, C.F.; Li, R.; Zhou, Z.; Shen, C.X. Exosomes Derived from Mesenchymal Stem Cells Rescue Myocardial Ischaemia/Reperfusion Injury by Inducing Cardiomyocyte Autophagy Via AMPK and Akt Pathways. Cell. Physiol. Biochem. Int. J. Exp. Cell. Physiol. Biochem. Pharmacol. 2017, 43, 52-68. [CrossRef] [PubMed]

60. Yu, B.; Kim, H.W.; Gong, M.; Wang, J.; Millard, R.W.; Wang, Y.; Ashraf, M.; Xu, M. Exosomes secreted from GATA-4 overexpressing mesenchymal stem cells serve as a reservoir of anti-apoptotic microRNAs for cardioprotection. Int. J. Cardiol. 2015, 182, 349-360. [CrossRef] [PubMed]

61. Liu, H.; Liu, S.; Qiu, X.; Yang, X.; Bao, L.; Pu, F.; Liu, X.; Li, C.; Xuan, K.; Zhou, J.; et al. Donor MSCs release apoptotic bodies to improve myocardial infarction via autophagy regulation in recipient cells. Autophagy 2020, 16, 2140-2155. [CrossRef] [PubMed]

62. Gupta, K.H.; Goldufsky, J.W.; Wood, S.J.; Tardi, N.J.; Moorthy, G.S.; Gilbert, D.Z.; Zayas, J.P.; Hahm, E.; Altintas, M.M.; Reiser, J.; et al. Apoptosis and Compensatory Proliferation Signaling Are Coupled by CrkI-Containing Microvesicles. Dev. Cell 2017, 41, 674-684.e675. [CrossRef] [PubMed]

63. Winau, F.; Weber, S.; Sad, S.; de Diego, J.; Hoops, S.L.; Breiden, B.; Sandhoff, K.; Brinkmann, V.; Kaufmann, S.H.; Schaible, U.E. Apoptotic vesicles crossprime CD8 T cells and protect against tuberculosis. Immunity 2006, 24, 105-117. [CrossRef]

64. Kranich, J.; Krautler, N.J.; Falsig, J.; Ballmer, B.; Li, S.; Hutter, G.; Schwarz, P.; Moos, R.; Julius, C.; Miele, G.; et al. Engulfment of cerebral apoptotic bodies controls the course of prion disease in a mouse strain-dependent manner. J. Exp. Med. 2010, 207, 2271-2281. [CrossRef] [PubMed]

65. Li, M.; Liao, L.; Tian, W. Extracellular Vesicles Derived from Apoptotic Cells: An Essential Link Between Death and Regeneration. Front. Cell Dev. Biol. 2020, 8, 573511. [CrossRef] [PubMed]

66. Schorey, J.S.; Cheng, Y.; Singh, P.P.; Smith, V.L. Exosomes and other extracellular vesicles in host-pathogen interactions. EMBO Rep. 2015, 16, 24-43. [CrossRef] [PubMed]

67. Kuipers, M.E.; Hokke, C.H.; Smits, H.H.; Nolte-'t Hoen, E.N.M. Pathogen-Derived Extracellular Vesicle-Associated Molecules That Affect the Host Immune System: An Overview. Front. Microbiol. 2018, 9, 2182. [CrossRef] [PubMed]

68. Munhoz da Rocha, I.F.; Amatuzzi, R.F.; Lucena, A.C.R.; Faoro, H.; Alves, L.R. Cross-Kingdom Extracellular Vesicles EV-RNA Communication as a Mechanism for Host-Pathogen Interaction. Front. Cell. Infect. Microbiol. 2020, 10, 593160. [CrossRef]

69. Martins, S.d.T.; Alves, L.R. Extracellular Vesicles in Viral Infections: Two Sides of the Same Coin? Front. Cell. Infect. Microbiol. 2020, 10, 593170. [CrossRef] [PubMed]

70. Rahimian, P.; He, J.J. Exosome-associated release, uptake, and neurotoxicity of HIV-1 Tat protein. J. Neurovirology 2016, 22, 774-788. [CrossRef] [PubMed]

71. Keryer-Bibens, C.; Pioche-Durieu, C.; Villemant, C.; Souquère, S.; Nishi, N.; Hirashima, M.; Middeldorp, J.; Busson, P. Exosomes released by EBV-infected nasopharyngeal carcinoma cells convey the viral Latent Membrane Protein 1 and the immunomodulatory protein galectin 9. BMC Cancer 2006, 6, 283. [CrossRef] [PubMed]

72. Balaji, K.N.; Goyal, G.; Narayana, Y.; Srinivas, M.; Chaturvedi, R.; Mohammad, S. Apoptosis triggered by Rv1818c, a PE family gene from Mycobacterium tuberculosis is regulated by mitochondrial intermediates in T cells. Microbes Infect. 2007, 9, 271-281. [CrossRef] [PubMed]

73. Vanaja, S.K.; Russo, A.J.; Behl, B.; Banerjee, I.; Yankova, M.; Deshmukh, S.D.; Rathinam, V.A.K. Bacterial Outer Membrane Vesicles Mediate Cytosolic Localization of LPS and Caspase-11 Activation. Cell 2016, 165, 1106-1119. [CrossRef] [PubMed]

74. Deo, P.; Chow, S.H.; Hay, I.D.; Kleifeld, O.; Costin, A.; Elgass, K.D.; Jiang, J.H.; Ramm, G.; Gabriel, K.; Dougan, G.; et al. Outer membrane vesicles from Neisseria gonorrhoeae target PorB to mitochondria and induce apoptosis. PLoS Pathog. 2018, 14, e1006945. [CrossRef]

75. Kunsmann, L.; Rüter, C.; Bauwens, A.; Greune, L.; Glüder, M.; Kemper, B.; Fruth, A.; Wai, S.N.; He, X.; Lloubes, R.; et al. Virulence from vesicles: Novel mechanisms of host cell injury by Escherichia coli O104:H4 outbreak strain. Sci. Rep. 2015, 5, 13252. [CrossRef]

76. Guay, C.; Kruit, J.K.; Rome, S.; Menoud, V.; Mulder, N.L.; Jurdzinski, A.; Mancarella, F.; Sebastiani, G.; Donda, A.; Gonzalez, B.J.; et al. Lymphocyte-Derived Exosomal MicroRNAs Promote Pancreatic $\beta$ Cell Death and May Contribute to Type 1 Diabetes Development. Cell Metab. 2019, 29, 348-361.e346. [CrossRef]

77. Wieckowski, E.U.; Visus, C.; Szajnik, M.; Szczepanski, M.J.; Storkus, W.J.; Whiteside, T.L. Tumor-derived microvesicles promote regulatory $\mathrm{T}$ cell expansion and induce apoptosis in tumor-reactive activated $\mathrm{CD} 8^{+} \mathrm{T}$ lymphocytes. J. Immunol. 2009, 183, 3720-3730. [CrossRef] [PubMed]

78. Mazzeo, C.; Cañas, J.A.; Zafra, M.P.; Rojas Marco, A.; Fernández-Nieto, M.; Sanz, V.; Mittelbrunn, M.; Izquierdo, M.; Baixaulli, F.; Sastre, J.; et al. Exosome secretion by eosinophils: A possible role in asthma pathogenesis. J. Allergy Clin. Immunol. 2015, 135, 1603-1613. [CrossRef] [PubMed]

79. Cañas, J.A.; Sastre, B.; Rodrigo-Muñoz, J.M.; Fernández-Nieto, M.; Barranco, P.; Quirce, S.; Sastre, J.; Del Pozo, V. Eosinophilderived exosomes contribute to asthma remodelling by activating structural lung cells. Clin. Exp. Allergy 2018, 48, 1173-1185. [CrossRef] [PubMed]

80. Mitra, S.; Exline, M.; Habyarimana, F.; Gavrilin, M.A.; Baker, P.J.; Masters, S.L.; Wewers, M.D.; Sarkar, A. Microparticulate Caspase 1 Regulates Gasdermin D and Pulmonary Vascular Endothelial Cell Injury. Am. J. Respir. Cell Mol. Biol. 2018, 59, 56-64. [CrossRef] [PubMed]

81. Mitra, S.; Wewers, M.D.; Sarkar, A. Mononuclear Phagocyte-Derived Microparticulate Caspase-1 Induces Pulmonary Vascular Endothelial Cell Injury. PLoS ONE 2015, 10, e0145607. [CrossRef] 
82. Kubo, H. Extracellular Vesicles in Lung Disease. Chest 2018, 153, 210-216. [CrossRef]

83. Medzhitov, R. Inflammation 2010: New adventures of an old flame. Cell 2010, 140, 771-776. [CrossRef] [PubMed]

84. Davidovich, P.; Kearney, C.J.; Martin, S.J. Inflammatory outcomes of apoptosis, necrosis and necroptosis. Biol. Chem. 2014, 395, 1163-1171. [CrossRef] [PubMed]

85. Jorgensen, I.; Miao, E.A. Pyroptotic cell death defends against intracellular pathogens. Immunol. Rev. 2015, $265,130-142$. [CrossRef]

86. Hannoodee, S.; Nasuruddin, D.N. Acute Inflammatory Response; StatPearls: Treasure Island, FL, USA, 2021.

87. Heneka, M.T.; Kummer, M.P.; Stutz, A.; Delekate, A.; Schwartz, S.; Vieira-Saecker, A.; Griep, A.; Axt, D.; Remus, A.; Tzeng, T.C.; et al. NLRP3 is activated in Alzheimer's disease and contributes to pathology in APP/PS1 mice. Nature 2013, 493, 674-678. [CrossRef] [PubMed]

88. Ising, C.; Venegas, C.; Zhang, S.; Scheiblich, H.; Schmidt, S.V.; Vieira-Saecker, A.; Schwartz, S.; Albasset, S.; McManus, R.M.; Tejera, D.; et al. NLRP3 inflammasome activation drives tau pathology. Nature 2019, 575, 669-673. [CrossRef] [PubMed]

89. Duewell, P.; Kono, H.; Rayner, K.J.; Sirois, C.M.; Vladimer, G.; Bauernfeind, F.G.; Abela, G.S.; Franchi, L.; Nunez, G.; Schnurr, M.; et al. NLRP3 inflammasomes are required for atherogenesis and activated by cholesterol crystals. Nature 2010, 464, 1357-1361. [CrossRef] [PubMed]

90. Chen, L.; Deng, H.; Cui, H.; Fang, J.; Zuo, Z.; Deng, J.; Li, Y.; Wang, X.; Zhao, L. Inflammatory responses and inflammationassociated diseases in organs. Oncotarget 2018, 9, 7204-7218. [CrossRef]

91. Raposo, G.; Nijman, H.W.; Stoorvogel, W.; Liejendekker, R.; Harding, C.V.; Melief, C.J.; Geuze, H.J. B lymphocytes secrete antigen-presenting vesicles. J. Exp. Med. 1996, 183, 1161-1172. [CrossRef]

92. Zitvogel, L.; Regnault, A.; Lozier, A.; Wolfers, J.; Flament, C.; Tenza, D.; Ricciardi-Castagnoli, P.; Raposo, G.; Amigorena, S. Eradication of established murine tumors using a novel cell-free vaccine: Dendritic cell-derived exosomes. Nat. Med. 1998, 4, 594-600. [CrossRef]

93. Gasser, O.; Schifferli, J.A. Activated polymorphonuclear neutrophils disseminate anti-inflammatory microparticles by ectocytosis. Blood 2004, 104, 2543-2548. [CrossRef] [PubMed]

94. Hardy, M.P.; Audemard, É.; Migneault, F.; Feghaly, A.; Brochu, S.; Gendron, P.; Boilard, É.; Major, F.; Dieudé, M.; Hébert, M.J.; et al. Apoptotic endothelial cells release small extracellular vesicles loaded with immunostimulatory viral-like RNAs. Sci. Rep. 2019, 9, 7203. [CrossRef] [PubMed]

95. Mardpour, S.; Hamidieh, A.A.; Taleahmad, S.; Sharifzad, F.; Taghikhani, A.; Baharvand, H. Interaction between mesenchymal stromal cell-derived extracellular vesicles and immune cells by distinct protein content. J. Cell Physiol. 2019, 234, 8249-8258. [CrossRef] [PubMed]

96. Obregon, C.; Rothen-Rutishauser, B.; Gerber, P.; Gehr, P.; Nicod, L.P. Active uptake of dendritic cell-derived exovesicles by epithelial cells induces the release of inflammatory mediators through a TNF-alpha-mediated pathway. Am. J. Pathol. 2009, 175, 696-705. [CrossRef] [PubMed]

97. Keerthikumar, S.; Chisanga, D.; Ariyaratne, D.; Al Saffar, H.; Anand, S.; Zhao, K.; Samuel, M.; Pathan, M.; Jois, M.; Chilamkurti, N.; et al. ExoCarta: A Web-Based Compendium of Exosomal Cargo. J. Mol. Biol. 2016, 428, 688-692. [CrossRef]

98. Park, K.S.; Choi, K.H.; Kim, Y.S.; Hong, B.S.; Kim, O.Y.; Kim, J.H.; Yoon, C.M.; Koh, G.Y.; Kim, Y.K.; Gho, Y.S. Outer membrane vesicles derived from Escherichia coli induce systemic inflammatory response syndrome. PLoS ONE 2010, 5, e11334. [CrossRef]

99. Lenassi, M.; Cagney, G.; Liao, M.; Vaupotic, T.; Bartholomeeusen, K.; Cheng, Y.; Krogan, N.J.; Plemenitas, A.; Peterlin, B.M. HIV Nef is secreted in exosomes and triggers apoptosis in bystander CD4+ T cells. Traffic 2010, 11, 110-122. [CrossRef]

100. Nieuwland, R.; Berckmans, R.J.; McGregor, S.; Boing, A.N.; Romijn, F.P.; Westendorp, R.G.; Hack, C.E.; Sturk, A. Cellular origin and procoagulant properties of microparticles in meningococcal sepsis. Blood 2000, 95, 930-935. [CrossRef]

101. Gao, K.; Jin, J.; Huang, C.; Li, J.; Luo, H.; Li, L.; Huang, Y.; Jiang, Y. Exosomes Derived from Septic Mouse Serum Modulate Immune Responses via Exosome-Associated Cytokines. Front. Immunol. 2019, 10, 1560. [CrossRef]

102. Fitzgerald, W.; Freeman, M.L.; Lederman, M.M.; Vasilieva, E.; Romero, R.; Margolis, L. A System of Cytokines Encapsulated in ExtraCellular Vesicles. Sci. Rep. 2018, 8, 8973. [CrossRef]

103. Fujimi, S.; Ogura, H.; Tanaka, H.; Koh, T.; Hosotsubo, H.; Nakamori, Y.; Kuwagata, Y.; Shimazu, T.; Sugimoto, H. Activated polymorphonuclear leukocytes enhance production of leukocyte microparticles with increased adhesion molecules in patients with sepsis. J. Trauma 2002, 52, 443-448. [CrossRef]

104. Shah, B.; Sullivan, C.J.; Lonergan, N.E.; Stanley, S.; Soult, M.C.; Britt, L.D. Circulating bacterial membrane vesicles cause sepsis in rats. Shock 2012, 37, 621-628. [CrossRef]

105. Gambim, M.H.; do Carmo Ade, O.; Marti, L.; Verissimo-Filho, S.; Lopes, L.R.; Janiszewski, M. Platelet-derived exosomes induce endothelial cell apoptosis through peroxynitrite generation: Experimental evidence for a novel mechanism of septic vascular dysfunction. Crit. Care 2007, 11, R107. [CrossRef]

106. Chen, L.; Yao, X.; Yao, H.; Ji, Q.; Ding, G.; Liu, X. Exosomal miR-103-3p from LPS-activated THP-1 macrophage contributes to the activation of hepatic stellate cells. FASEB J. 2020, 34, 5178-5192. [CrossRef] [PubMed]

107. Timar, C.I.; Lorincz, A.M.; Csepanyi-Komi, R.; Valyi-Nagy, A.; Nagy, G.; Buzas, E.I.; Ivanyi, Z.; Kittel, A.; Powell, D.W.; McLeish, K.R.; et al. Antibacterial effect of microvesicles released from human neutrophilic granulocytes. Blood 2013, 121, 510-518. [CrossRef] [PubMed] 
108. Mostefai, H.A.; Meziani, F.; Mastronardi, M.L.; Agouni, A.; Heymes, C.; Sargentini, C.; Asfar, P.; Martinez, M.C.; Andriantsitohaina, R. Circulating microparticles from patients with septic shock exert protective role in vascular function. Am. J. Respir. Crit. Care Med. 2008, 178, 1148-1155. [CrossRef]

109. Dalli, J.; Norling, L.V.; Montero-Melendez, T.; Federici Canova, D.; Lashin, H.; Pavlov, A.M.; Sukhorukov, G.B.; Hinds, C.J.; Perretti, M. Microparticle alpha-2-macroglobulin enhances pro-resolving responses and promotes survival in sepsis. EMBO Mol. Med. 2014, 6, 27-42. [CrossRef] [PubMed]

110. Miksa, M.; Wu, R.; Dong, W.; Komura, H.; Amin, D.; Ji, Y.; Wang, Z.; Wang, H.; Ravikumar, T.S.; Tracey, K.J.; et al. Immature dendritic cell-derived exosomes rescue septic animals via milk fat globule epidermal growth factor-factor VIII [corrected]. J. Immunol. 2009, 183, 5983-5990. [CrossRef]

111. Kesimer, M.; Scull, M.; Brighton, B.; DeMaria, G.; Burns, K.; O’Neal, W.; Pickles, R.J.; Sheehan, J.K. Characterization of exosomelike vesicles released from human tracheobronchial ciliated epithelium: A possible role in innate defense. FASEB J. 2009, 23, 1858-1868. [CrossRef] [PubMed]

112. Bourdonnay, E.; Zaslona, Z.; Penke, L.R.; Speth, J.M.; Schneider, D.J.; Przybranowski, S.; Swanson, J.A.; Mancuso, P.; Freeman, C.M.; Curtis, J.L.; et al. Transcellular delivery of vesicular SOCS proteins from macrophages to epithelial cells blunts inflammatory signaling. J. Exp. Med. 2015, 212, 729-742. [CrossRef]

113. Moon, H.G.; Kim, S.H.; Gao, J.; Quan, T.; Qin, Z.; Osorio, J.C.; Rosas, I.O.; Wu, M.; Tesfaigzi, Y.; Jin, Y. CCN1 secretion and cleavage regulate the lung epithelial cell functions after cigarette smoke. Am. J. Physiol. Lung Cell Mol. Physiol. 2014, 307, L326-L337. [CrossRef]

114. Kulshreshtha, A.; Ahmad, T.; Agrawal, A.; Ghosh, B. Proinflammatory role of epithelial cell-derived exosomes in allergic airway inflammation. J. Allergy Clin. Immunol. 2013, 131, 1194-1203.e14. [CrossRef] [PubMed]

115. Skokos, D.; Le Panse, S.; Villa, I.; Rousselle, J.C.; Peronet, R.; Namane, A.; David, B.; Mecheri, S. Nonspecific B and T cellstimulatory activity mediated by mast cells is associated with exosomes. Int. Arch. Allergy Immunol. 2001, 124, 133-136. [CrossRef] [PubMed]

116. Xie, G.; Yang, H.; Peng, X.; Lin, L.; Wang, J.; Lin, K.; Cui, Z.; Li, J.; Xiao, H.; Liang, Y.; et al. Mast cell exosomes can suppress allergic reactions by binding to IgE. J. Allergy Clin. Immunol. 2018, 141, 788-791. [CrossRef] [PubMed]

117. Canas, J.A.; Sastre, B.; Mazzeo, C.; Fernandez-Nieto, M.; Rodrigo-Munoz, J.M.; Gonzalez-Guerra, A.; Izquierdo, M.; Barranco, P.; Quirce, S.; Sastre, J.; et al. Exosomes from eosinophils autoregulate and promote eosinophil functions. J. Leukoc. Biol. 2017, 101, 1191-1199. [CrossRef]

118. Admyre, C.; Johansson, S.M.; Paulie, S.; Gabrielsson, S. Direct exosome stimulation of peripheral human T cells detected by ELISPOT. Eur. J. Immunol. 2006, 36, 1772-1781. [CrossRef]

119. Admyre, C.; Bohle, B.; Johansson, S.M.; Focke-Tejkl, M.; Valenta, R.; Scheynius, A.; Gabrielsson, S. B cell-derived exosomes can present allergen peptides and activate allergen-specific T cells to proliferate and produce TH2-like cytokines. J. Allergy Clin. Immunol. 2007, 120, 1418-1424. [CrossRef]

120. Hassanpour, M.; Rezaie, J.; Nouri, M.; Panahi, Y. The role of extracellular vesicles in COVID-19 virus infection. Infect. Genet. Evol. 2020, 85, 104422. [CrossRef]

121. Balbi, C.; Burrello, J.; Bolis, S.; Lazzarini, E.; Biemmi, V.; Pianezzi, E.; Burrello, A.; Caporali, E.; Grazioli, L.G.; Martinetti, G.; et al. Circulating extracellular vesicles are endowed with enhanced procoagulant activity in SARS-CoV-2 infection. EBioMedicine 2021, 67, 103369. [CrossRef]

122. Guervilly, C.; Bonifay, A.; Burtey, S.; Sabatier, F.; Cauchois, R.; Abdili, E.; Arnaud, L.; Lano, G.; Pietri, L.; Robert, T.; et al. Dissemination of extreme levels of extracellular vesicles: Tissue factor activity in patients with severe COVID-19. Blood Adv. 2021, 5, 628-634. [CrossRef]

123. Sengupta, V.; Sengupta, S.; Lazo, A.; Woods, P.; Nolan, A.; Bremer, N. Exosomes Derived from Bone Marrow Mesenchymal Stem Cells as Treatment for Severe COVID-19. Stem Cells Dev. 2020, 29, 747-754. [CrossRef] [PubMed]

124. Hotchkiss, R.S.; Moldawer, L.L.; Opal, S.M.; Reinhart, K.; Turnbull, I.R.; Vincent, J.L. Sepsis and septic shock. Nat. Rev. Dis. Primers 2016, 2, 16045. [CrossRef] [PubMed]

125. Raeven, P.; Zipperle, J.; Drechsler, S. Extracellular Vesicles as Markers and Mediators in Sepsis. Theranostics 2018, 8, 3348-3365. [CrossRef]

126. Labbe, K.; Saleh, M. Cell death in the host response to infection. Cell Death Differ. 2008, 15, 1339-1349. [CrossRef] [PubMed]

127. Vincent, J.L.; Sakr, Y.; Sprung, C.L.; Ranieri, V.M.; Reinhart, K.; Gerlach, H.; Moreno, R.; Carlet, J.; Le Gall, J.R.; Payen, D.; et al. Sepsis in European intensive care units: Results of the SOAP study. Crit. Care Med. 2006, 34, 344-353. [CrossRef] [PubMed]

128. Hotchkiss, R.S.; Nicholson, D.W. Apoptosis and caspases regulate death and inflammation in sepsis. Nat. Rev. Immunol. 2006, 6, 813-822. [CrossRef] [PubMed]

129. Kim, O.Y.; Choi, S.J.; Jang, S.C.; Park, K.S.; Kim, S.R.; Choi, J.P.; Lim, J.H.; Lee, S.W.; Park, J.; Di Vizio, D.; et al. Bacterial protoplast-derived nanovesicles as vaccine delivery system against bacterial infection. Nano Lett. 2015, 15, 266-274. [CrossRef]

130. Larsson, A.; Lundahl, T.; Eriksson, M.; Lundkvist, K.; Lindahl, T. Endotoxin induced platelet microvesicle formation measured by flow cytometry. Platelets 1996, 7, 153-158. [CrossRef] [PubMed]

131. Lee, Y.J.; Jy, W.; Horstman, L.L.; Janania, J.; Reyes, Y.; Kelley, R.E.; Ahn, Y.S. Elevated platelet microparticles in transient ischemic attacks, lacunar infarcts, and multiinfarct dementias. Thromb. Res. 1993, 72, 295-304. [CrossRef] 
132. Holme, P.A.; Solum, N.O.; Brosstad, F.; Roger, M.; Abdelnoor, M. Demonstration of platelet-derived microvesicles in blood from patients with activated coagulation and fibrinolysis using a filtration technique and western blotting. Thromb. Haemost. 1994, 72 , 666-671.

133. Lundahl, T.H.; Lindahl, T.L.; Fagerberg, I.H.; Egberg, N.; Bunescu, A.; Larsson, A. Activated platelets and impaired platelet function in intensive care patients analyzed by flow cytometry. Blood Coagul. Fibrinolysis 1996, 7, 218-220. [CrossRef] [PubMed]

134. Denning, N.L.; Aziz, M.; Gurien, S.D.; Wang, P. DAMPs and NETs in Sepsis. Front. Immunol. 2019, 10, 2536. [CrossRef]

135. Gangoda, L.; Schenk, R.L.; Best, S.A.; Nedeva, C.; Louis, C.; D'Silva, D.B.; Fairfax, K.; Jarnicki, A.G.; Puthalakath, H.; Sutherland, K.D.; et al. Absence of pro-survival A1 has no impact on inflammatory cell survival in vivo during acute lung inflammation and peritonitis. Cell Death Differ. 2021. [CrossRef] [PubMed]

136. Nedeva, C.; Menassa, J.; Duan, M.; Liu, C.; Doerflinger, M.; Kueh, A.J.; Herold, M.J.; Fonseka, P.; Phan, T.K.; Faou, P.; et al. TREML4 receptor regulates inflammation and innate immune cell death during polymicrobial sepsis. Nat. Immunol. 2020, 21, 1585-1596. [CrossRef] [PubMed]

137. Herrmann, I.K.; Bertazzo, S.; O'Callaghan, D.J.; Schlegel, A.A.; Kallepitis, C.; Antcliffe, D.B.; Gordon, A.C.; Stevens, M.M. Differentiating sepsis from non-infectious systemic inflammation based on microvesicle-bacteria aggregation. Nanoscale 2015, 7, 13511-13520. [CrossRef] [PubMed]

138. Essandoh, K.; Yang, L.; Wang, X.; Huang, W.; Qin, D.; Hao, J.; Wang, Y.; Zingarelli, B.; Peng, T.; Fan, G.C. Blockade of exosome generation with GW4869 dampens the sepsis-induced inflammation and cardiac dysfunction. Biochim. Biophys. Acta 2015, 1852, 2362-2371. [CrossRef]

139. Ren, C.; Yao, R.Q.; Zhang, H.; Feng, Y.W.; Yao, Y.M. Sepsis-associated encephalopathy: A vicious cycle of immunosuppression. J. Neuroinflammation 2020, 17, 14. [CrossRef]

140. Xu, Y.; Ku, X.; Wu, C.; Cai, C.; Tang, J.; Yan, W. Exosomal proteome analysis of human plasma to monitor sepsis progression. Biochem. Biophys. Res. Commun. 2018, 499, 856-861. [CrossRef] [PubMed]

141. Englert, J.A.; Bobba, C.; Baron, R.M. Integrating molecular pathogenesis and clinical translation in sepsis-induced acute respiratory distress syndrome. JCI Insight 2019, 4, e124061. [CrossRef]

142. Fujita, Y.; Kosaka, N.; Araya, J.; Kuwano, K.; Ochiya, T. Extracellular vesicles in lung microenvironment and pathogenesis. Trends Mol. Med. 2015, 21, 533-542. [CrossRef] [PubMed]

143. Mohan, A.; Agarwal, S.; Clauss, M.; Britt, N.S.; Dhillon, N.K. Extracellular vesicles: Novel communicators in lung diseases. Respir. Res. 2020, 21, 175. [CrossRef]

144. Letsiou, E.; Sammani, S.; Zhang, W.; Zhou, T.; Quijada, H.; Moreno-Vinasco, L.; Dudek, S.M.; Garcia, J.G. Pathologic mechanical stress and endotoxin exposure increases lung endothelial microparticle shedding. Am. J. Respir. Cell Mol. Biol. 2015, 52, 193-204. [CrossRef] [PubMed]

145. Li, C.J.; Liu, Y.; Chen, Y.; Yu, D.; Williams, K.J.; Liu, M.L. Novel proteolytic microvesicles released from human macrophages after exposure to tobacco smoke. Am. J. Pathol. 2013, 182, 1552-1562. [CrossRef] [PubMed]

146. Moon, H.G.; Zheng, Y.; An, C.H.; Kim, Y.K.; Jin, Y. CCN1 secretion induced by cigarette smoking extracts augments IL-8 release from bronchial epithelial cells. PLoS ONE 2013, 8, e68199. [CrossRef] [PubMed]

147. Schutze, N.; Rucker, N.; Muller, J.; Adamski, J.; Jakob, F. 5' flanking sequence of the human immediate early responsive gene ccn1 (cyr61) and mapping of polymorphic CA repeat sequence motifs in the human ccn1 (cyr61) locus. Mol. Pathol. 2001, 54, 170-175. [CrossRef]

148. Hamid, Q.; Tulic, M.K.; Liu, M.C.; Moqbel, R. Inflammatory cells in asthma: Mechanisms and implications for therapy. J. Allergy Clin. Immunol. 2003, 111, S5-S12. [CrossRef] [PubMed]

149. Lee, K.Y. Pneumonia, Acute Respiratory Distress Syndrome, and Early Immune-Modulator Therapy. Int. J. Mol. Sci. 2017, 18, 388 [CrossRef] [PubMed]

150. Tsushima, K.; King, L.S.; Aggarwal, N.R.; De Gorordo, A.; D'Alessio, F.R.; Kubo, K. Acute lung injury review. Intern. Med. 2009, 48, 621-630. [CrossRef] [PubMed]

151. Matthay, M.A.; Ware, L.B.; Zimmerman, G.A. The acute respiratory distress syndrome. J. Clin. Invest. 2012, 122, 2731-2740. [CrossRef]

152. Lee, H.; Zhang, D.; Laskin, D.L.; Jin, Y. Functional Evidence of Pulmonary Extracellular Vesicles in Infectious and Noninfectious Lung Inflammation. J. Immunol. 2018, 201, 1500-1509. [CrossRef] [PubMed]

153. Jiang, K.; Yang, J.; Guo, S.; Zhao, G.; Wu, H.; Deng, G. Peripheral Circulating Exosome-Mediated Delivery of miR-155 as a Novel Mechanism for Acute Lung Inflammation. Mol. Ther. 2019, 27, 1758-1771. [CrossRef] [PubMed]

154. Pocsfalvi, G.; Mammadova, R.; Ramos Juarez, A.P.; Bokka, R.; Trepiccione, F.; Capasso, G. COVID-19 and Extracellular Vesicles: An Intriguing Interplay. Kidney Blood Press Res. 2020, 45, 661-670. [CrossRef]

155. Rodrigues, T.S.; de Sa, K.S.G.; Ishimoto, A.Y.; Becerra, A.; Oliveira, S.; Almeida, L.; Goncalves, A.V.; Perucello, D.B.; Andrade, W.A.; Castro, R.; et al. Inflammasomes are activated in response to SARS-CoV-2 infection and are associated with COVID-19 severity in patients. J. Exp. Med. 2021, 218, e20201707. [CrossRef]

156. Xiao, K.; Hou, F.; Huang, X.; Li, B.; Qian, Z.R.; Xie, L. Mesenchymal stem cells: Current clinical progress in ARDS and COVID-19. Stem Cell Res. Ther. 2020, 11, 305. [CrossRef] 
157. Barberis, E.; Vanella, V.V.; Falasca, M.; Caneapero, V.; Cappellano, G.; Raineri, D.; Ghirimoldi, M.; De Giorgis, V.; Puricelli, C.; Vaschetto, R.; et al. Circulating Exosomes Are Strongly Involved in SARS-CoV-2 Infection. Front. Mol. Biosci. 2021, 8, 632290. [CrossRef] [PubMed]

158. Song, J.W.; Lam, S.M.; Fan, X.; Cao, W.J.; Wang, S.Y.; Tian, H.; Chua, G.H.; Zhang, C.; Meng, F.P.; Xu, Z.; et al. Omics-Driven Systems Interrogation of Metabolic Dysregulation in COVID-19 Pathogenesis. Cell Metab. 2020, 32, 188-202.e185. [CrossRef]

159. Cocozza, F.; Nevo, N.; Piovesana, E.; Lahaye, X.; Buchrieser, J.; Schwartz, O.; Manel, N.; Tkach, M.; Thery, C.; Martin-Jaular, L. Extracellular vesicles containing ACE2 efficiently prevent infection by SARS-CoV-2 Spike protein-containing virus. J. Extracell. Vesicles 2020, 10, e12050. [CrossRef]

160. Tsiapalis, D.; O’Driscoll, L. Mesenchymal Stem Cell Derived Extracellular Vesicles for Tissue Engineering and Regenerative Medicine Applications. Cells 2020, 9, 911. [CrossRef]

161. O'Driscoll, L. Extracellular vesicles from mesenchymal stem cells as a Covid-19 treatment. Drug Discov. Today 2020, 25, 1124-1125. [CrossRef] [PubMed]

162. Khalaj, K.; Figueira, R.L.; Antounians, L.; Lauriti, G.; Zani, A. Systematic review of extracellular vesicle-based treatments for lung injury: Are EVs a potential therapy for COVID-19? J. Extracell. Vesicles 2020, 9, 1795365. [CrossRef]

163. Xia, X.; Yuan, P.; Liu, Y.; Wang, Y.; Cao, W.; Zheng, J.C. Emerging roles of extracellular vesicles in COVID-19, a double-edged sword? Immunology 2021, 163, 416-430. [CrossRef] [PubMed] 